\title{
The Value of Irony: Legal Orthodoxy and Henry James's Washington Square
}

\author{
Ticien Marie Sassoubre $\dagger$
}

\section{INTRODUCTION}

In the following pages, I offer a close reading of Henry James's 1880 novel, Washington Square. My purpose is to show that representations of law in American fiction offer unique and valuable resources for understanding the intersection of legal texts, legal interpretation, and lived experience. This project participates in a recent trend of thinking about law as both a part and product of culture. 'The cultural study of law begins with the recognition "that legal meaning is found and invented in the variety of locations and practices that comprise culture and that those locations and practices are themselves encapsulated, though always incompletely, in legal forms, regulations, and legal symbols." Applications of this insight have been diverse in subject and approach, since

Copyright (C) 2007 California Law Review, Inc. California Law Review, Inc. (CLR) is a California nonprofit corporation. CLR and the authors are solely responsible for the content of their publications.

$\dagger$ Lecturer in Residence, Boalt Hall School of Law, UC Berkeley. B.A. 1994, Williams College; Ph.D. (English) 2001, Stanford University. I am grateful to Norman W. Spaulding, Barbara Allen Babcock, Amnon Reichman, and Thomas C. Grey for their thoughtful comments and to Alice Youmans for assistance in the early stages of the project. James Keenley and Emily Bolt provided valuable research assistance. I am also indebted to George Dekker for first suggesting that I write about Washington Square.

1. See, e.g., Cultural Analysis, Cultural Studies, and the law (Austin Sarat \& Jonathan Simon eds., 2003); LAW and THE Order of Culture (Robert Post ed., 1991); LAW IN THE Domains of Culture (Austin Sarat \& Thomas R. Kearns eds., 1998). Further explorations of the intersection of law and culture include Paul W. KahN, The Cultural Study of Law (1999); Robert Cover, Forward: Nomos and Narrative, 97 HARv. L. REv. 4 (I984) (an early foray into the field); and Susan S. Silbey, Making a Place for Cultural Analyses of Law, 17 LAw \& Soc. INQUIRY 39 (1992).

2. Austin Sarat \& Jonathan Simon, Cultural Analysis, Cultural Studies, and the Situation of Legal Scholarship, in Cultural Analysis, Cultural Studies, and the Law 15 (Austin Sarat \& Jonathan Simon eds., 2003).

3. Naomi Mezey, Law as Culture, in Cultural Analysis, Cultural Studies, and the LAw 37, 45-46 (Austin Sarat \& Jonathan Simon eds., 2003). 
the insights and methodologies of cultural studies tend to operate in the realm of the particular, offering interpretations of specific cultural artifacts or historical moments, ${ }^{4}$ rather than free-standing rubrics-such as supply and demand or information costs--which might be applied, ready-made, to legal contexts. ${ }^{5}$ But it is in the habit and apparatus of attending to context, in all its complexity and messiness, that the value of cultural studies for legal discourse lies: attending to the subjective, everyday experience of the cultural processes, including law, that make our world. ${ }^{6}$

Literature and literary criticism have long practice attending to the subjective experience of cultural processes-the establishment and maintenance of class hierarchies, the routinization of work, the influence of mass media, the effects of ideological conflict - as well as to the rhetorical and narrative structures that shape personal and communal identities. The considerable promise that the study of literature thus holds for law has been widely recognized. ${ }^{7}$ Legal scholars have been particularly interested in the overlapping elements of narrative and interpretation in law and literature. ${ }^{8}$ But

4. Sarat and Simon assert that "eultural studies consists of tools for tracking the production of subject positions as well as of a growing set of 'ease studies' in the subjective history of power in modern liberal democracies." Sarat \& Simon, supra note 2, at 8-9, 16; see also Mezey, supra note 3 , at 61 (" 1 suspect that the cultural study of law will never attain the status of law and economics within law schools precisely because, rather than simplifymg law, it complicates it."). The anthologies in note 1 offer a representative sampling of this diversity.

5. In this way it contrasts rather starkly with the law and economics movement, which has come to enjoy a mainstream position in legal discourse. See Robert Cooter \& Thomas Ulen, Law and Economics (1988); A. Mitchell Polinski, An Introduction to Law and Economics (2d ed. 1988); Guido Calebresi, Some Thoughts on Risk Distribution and the Law of Torts, 70 YAle L.J. 499 (1961); R. H. Coase, The Problem of Social Cost, 3 J.L. \& Econ. 1 (1960). The cultural study of law builds on, but also differs from, the law and society movement. See Sarat \& Simon, supra note 2, at 1-9. On the law and society movement generally; see, e.g., The Law and Society Reader (Richard L. Abel ed., 1995); The Politics of Law (David Kairys ed., 3d ed. 1998).

6. There is an emerging consensus that culture ought to be regarded, in Raymond Williams's words, 'as the signifying system through which necessarily (though among other means) a social order is communicated, reproduced, experienced, and explored.' Culture, we have come fmally to believe, is the precondition for the very possibility of human meaning, and it is not merely ornamental, but engaged in the hard, practical, and important work of reproducing the social order.

Robert Post, The Relatively Autonomous Discourse of Law, in LAW AND THE ORder of CULTURE vii (Robert Post ed., 1991) (emphasis in original).

7. For an excellent overview of the law and literature movement, see GUYORA BINDER \& Robert WeIsberg, Literary Criticisms of Law 3-27 (2000). See also INTERPRETING LaW aNd Literature: A Hermeneutic Reader (Sanford Levinson \& Steven Mailloux eds., 1988); LAW and Literature (Patrick Hanafin, Adam Gearey \& Joseph Brooke eds., 2004); LAW AND Literature: TeXt AND Theory (Lenora Ledwon ed., 1996).

8. On the use of rhetorical and literary critical tools on legal texts, see, for example, Binder \& Weisberg, supra note 7, at 112-462; Stanley Fish, Doing What Comes Naturally (1989); James Boyd White, Heracles's Bow (1985). On the role of narrative in legal discourse, see, for example, LAW's Stories: NarRative and RhEToRIC IN THE LAW (Peter 
the analysis of literary representations of law is also apposite to legal scholarship. ${ }^{9}$ Fictional texts often capture the disjuncture between the intentions and aspirations of law and specific legal outcomes-the "slippage" between "law's aims and effects"-more concretely and with more nuance than other cultural artifacts. ${ }^{10}$ Think, for example, of the unexpected consequences of Hester's punishment for her lover and her community in The Scarlet Letter, or the moral outrage that the entirely legal pursuit of Eliza and her child provokes in Uncle Tom's Cabin. Fiction is also uniquely situated to capture the "collision of cultural and legal meanings" in everyday, subjective experience." In The Adventures of Huckleberry Finn, Jim is both a fugitive slave and Huck's friend and surrogate guardian; in The Great Gatsby, Jay Gatsby is considered criminal for aspiring to the social class of the Buchanans, but the Buchanans think nothing of covering up a murder.

Moreover, the particular ways that fictional texts register the intersections of law and culture in lived experience disclose the important role that language itself plays in the "processes by which law contributes to the articulation of meanings and values in daily life." 12 In Washington Square, for example, the pervasiveness of what we would think of as legal discourse in extralegal settings demonstrates the interpenetration of legal and non-legal vocabularies. The effects of this interpenetration are not merely conceptual or ideological.

Brooks \& Paul Gewirtz eds., 1996); John M. Conley \& William M. O'Barr, Just Words: Law, Language, and Power (1998); Kathryn Abrams, Hearing the Call of Stories, 79 CALIF. L. Rev. 971 (1991); Patricia Ewick \& Susan S. Silbey, Subversive Stories and Hegemonic Tales: Toward a Sociology of Narrative, 29 LAw \& Soc'y REv. 197 (1995).

9. For examples of the analysis of literary representations of law, see, for example, WAI Chee Dimock, Residues of Justice: Literature, Law, Philosophy (1996); Literature and Law (Michael J. Jeyer ed., 2005); Walter Benn Michaels, The Gold Standard and the Logic of Naturalism (1988); Brook Thomas, American Literary Realism and the Failed Promise of Contract (1997); Brook Thomas, Cross-Examinations of Law and Literature: Cooper, Hawthorne, Stowe and Melville (1987); Richard Weisberg, The Failure of the Word: The Protagonist as Lawyer in Modern Fiction (1984); Symposium, The Failure of the Word, 96 CARDozo L. REv. (2005). According to Binder and Weisberg:

Law and Literature scholarship ought to constitute an experiment in rebuilding the aesthetic in legal terms or the legal in aesthetic terms. It might show how literary apprehensions of social or psychological reality borrow from the legal apprehension of social and psychological reality. Or it might show some symbiosis or conspiracy between the legal control of political energy and the cultural forms of imaginative meaning making we normally associate with the literary. Whatever the specific insights, the value of such research resides not in any confirmation of the power of a single method to subject an ever broader domain of data to a sovereign theory, but in an artful disjunction of method and data to illuminate a particular society's images of and beliefs about itself.

WEISBERG \& BINDER, supra note 7, at 466.

10. Naomi Mezey has argued that the cultural study of law can and should offer "complex account $[\mathrm{s}]$ of the slippage between the production and the reeption of law and legal meanings, of the ways in which spccific cultural practices or identities coincide or collide with specific legal rules or conventions, thereby altering the meanings of both." Mezey, supra note 3, at 54 .

11. Id.

12. Silbey, supra note I, at 42 . 
The contending vocabularies in the text correspond to ideological positions but also to material and social conditions and the assumptions and expectations that simultaneously shape and are shaped by lived experience. In other words, the cultural work of legal language is made concrete in the novel through its characters' choices, identities, and actions.

"They invent everything all over again about every five years," the young stockbroker, Arthur Townsend, observes in Washington Square, "and it's a great thing to keep up with the new things. I always try and keep up with the new things of every kind." 13 The frenetic vagueness of Townsend's pronouncement reflects the social and material upheaval of the postbellum period. The "new things" to which Townsend refers include a rapidly expanding New York City ${ }^{14}$ and the proliferation of mass-produced products suddenly available in department stores. ${ }^{15}$ Even Townsend's profession is new, as is the concentration of wealth into corporate holdings that fuels the stock exchange. ${ }^{16}$ And the new things of the era extended well beyond New York. Westward expansion fueled by railroads and land speculation was rapidly closing the frontier ${ }^{17}$ at the same time that unprecedented numbers of Americans were moving to urban centers to work for wages. ${ }^{18}$ Immigrants from increasingly diverse parts of Europe were pouring into urban centers. ${ }^{19}$ Technology was transforming both the way people worked and the way they

13. Henry James, Washington Square 32-33 (Signet Classics 18th printing 1979).

14. "Even before the Civil War, American cities had begun to experience major change. ... The decades following the war witnessed a major acceleration, striking many contemporaries as a radical departure." Alan Trachtenberg, The Incorporation of America: Culture \& SocieTY IN THE GILDED AgE 115 (1982). In 1850, New York City's population was 515,547. By 1880 , it had more than doubled, to $1,206,299$. U.S. Census, Population of the 100 Largest Citics and Other Urban Places in the United States: 1790 to 1990, http://www.census.gov/population/ www/documentation/twps0027.html.

15. "Of all city speetacles, none surpassed the giant department store, the emporium of consumption born and nurtured in these years. Here the citizen met a new world of goods: not goods alone, but a world of goods, constructed and shaped by the store into objects of desire." TRACHTENBERG, supra note 14, at 130 (emphasis in original).

16. Martin J. Sklar, The Corporate Reconstruction of american Capitalism, I 890-I9I6 44 (1988). In the postbellum period, "corporate-administered capitalism" was taking hold of the American economy, supplanting the prior regime of more local, community-based "proprietary capitalism." Id. at 4.

The corporate reorganization of eapitalist property and market relations substantially affeeted, or integrally related to, changes in intra-class and interclass relations, in law and public policy, in party politics, in international rclations, in prevalent modes of social thought, in education and philanthropy, in civic association, in the structure and role of government, and in the government-society relation in general.

Id. at 5; see also Karl Polanyi, The Great Transformation (1957).

17. Trachtenberg, supra note 14, at 11-37; see also Frederick Jackson Turner, The Frontier in American History 1-39 (1920).

18. Robert H. Wiebe, The Search for Order, I877-1920 12 (1967).

19. Id. at 14 . 
spent their leisure time. ${ }^{20}$ These and other changes not only transformed the way Americans lived, but also changed the relationships between Americans. ${ }^{21}$ Indeed, the postbellum period "marked a watershed of clashing perspectives and practices." 22

As Tocqueville had observed half a century earlier, "Scarcely any political question arises in the United States that is not resolved, sooner or later, into a judicial question." 23 The law was quickly and broadly imbricated in the clashing perspectives and practices of the postbellum period, from contract disputes between workers and owners ${ }^{24}$ to the maintenance of race relations in the recently "redeemed" South ${ }^{25}$ to the implications of the reconstruction amendments for federalism. ${ }^{26}$ Lawyers "found themselves in the awkward position of trying to define a world they feared and understood only imperfectly with concepts that were outmoded and ill suited to the task." ${ }^{27}$ One of the results was the emergence of a new "legal science," which quickly came to dominate postbellum legal discourse in no small part because it promised "a

20. TRACHETENBERG, supra note 14 , at 62 (on the pressures to increase productivity and their effects on the organization of labor) and 129 (on the mass media's invention of a new conception of home life).

21. "Social definitions of basic categories-capital, labor, enterprise, work, ownership—all underwent shifting and sliding alterations in the watershed decades of the $1870 \mathrm{~s}$ and $1880 \mathrm{~s}$. The rapidity of change left in its wake confusion and anger, a loss of bearings, and a gathering of forces." TRACHTENBERG, supra note 14, at 79-80.

22. "Historians have long recognized that changes in business organization were associated with other historical developments such as the rise of the metropolis, a revolution in transportation and communications, and the processes of secularization, bureaucratization, and professionalization. Hardly any realm of Amcrican life remained untouched." TRACHTENBERG, supra note 14, at 5. See generally W1EBE, supra note 18.

23. Alexis de Tocqueville, Democracy in America 280 (Encyclopedia Britannica, Inc. $2 d$ cd. 1990).

24. See generally William E. Forbath, The Ambiguities of Free Labor: Labor and the Law in the Gilded Age, 1985 WIS. L. Rev. 767 (1985). See also TraChTENBERG, supra note 14, at 70100; William M. Wiecek, The Lost World of Classical Legal Thought 68-77 (1998).

25. See C. VanN Woodward, Origins of THE New South, 1877-1913 23-74 (1951). Redemption-the return of Southern states to home rule-began in Mississippi in 1875. See generally ERIC Foner, ReCONSTRUCTION: America's Unfinished Revolution, 1863-1877 (1988); Kenneth StampP, The Era of Reconstruction, 1865-1877 (1965).

26. See Harold M. Hyman and William M. Wiecek, EQUAL JUSTICE UNDER LAW: CONSTITUTIONAL DEVELOPMENT 1835-1875 232-515 (1982); Wiecek, supra note 24, at 67.

27. WIECEK, supra note 24 , at 68 .

Hurtling social and economic change-the triad of industrialization, urbanization, and immigration in the late nineteenth century-outran the ability of Americans to formulate ideological structures that would help them understand such change, much less control it. . . In the domain of lcgal thought, cultural lag took the form of jurists and lawyers attempting to adapt legal concepts and structures of thought (ideologies) that had governed an earlier age to the drastically changed circumstanccs of the new environment.

Id. at 66-67; see also Robert W. Gordon, Legal Thought and Legal Practice in the Age of American Enterprise, 1870-1920, in Professions and Professional ldeologies in America (Gerald Geison ed., 1983). 
comprehensive vision of law" apparently insulated from social and economic upheaval. ${ }^{28}$ Legal science aspired to systematize law by "gathering rules from decided cases, generalizing to principles, harmonizing those principles into a system by classifying them," and finally producing "rules that would resolve particular cases impartially, justly, and consistently." 29 And as one of the new things in the late nineteenth century, the influence of legal science was felt well beyond the confines of legal discourse. ${ }^{30}$

The aspiration of legal science to make law "complete through universal formality, and universally formal through conceptual order",31 was undermined by both the actual complexity of the common law $^{32}$ and an overconfidence in the ordering powers of logic inherent in legal science's method. ${ }^{33}$ As the

28. W1ECEK, supra note 24 , at 79. Legal science

provided an explanation of what law was, what its sources and sanctions were, why it could command the obcdience of all, how it animated socicty and directed the economic order. . . . Classical thought intcgrated society, economy, and law as it sanctioned the status quo of the American social order.

Id. at 64. Legal science dominated American legal thought from 1870 into the 1930s. The date of inception is keyed to Christopher Columbus Langdell's appointment as dean of Harvard Law School, where he introduced the case method and championed the idea of law as science. Thomas C. Grey, Langdell's Orthodoxy, 45 U. PITT L. Rev 1, 1-3 (1983); WIECEK, supra note 24, at 9293. The ideal of a science of law "had considerable continuity" with antebellum legal aspirations. Grey, supra, at 5; WIECEK, supra note 24, at 37-54. But it was not until the 1870 s that American legal thinkers undertook systematically to "derive correct legal judgments from a few fundamental principles and concepts." Grey, supra, at 5. Grey refers to this movement as "classical orthodoxy" and subsequent treatments have employed a similar nomenclature: William Wiecek uses "classical legal thought" and "legal classicism" and Morton Horwitz uscs "classical legal thought" and "classical orthodoxy." Morton Horwitz, The Transformation of American Law, 18701960, 36 (1992). Wiecck and others, including, more recently, Wai Chee Dimock, also use "legal science" to describe the movement. Wai Chce Dimock, Rules of Law, Laws of Science, in Cultural analysis, Cultural Studies, and the Law 220 (Austin Sarat \& Jonathan Simon eds., 2003).

29. WIECEK, supra note 24 , at 91 . The result, at least theoretically, would be ncutral, apolitical, and objective. See Grey, supra note 28, at 32-39, W1ECEK, supra note 24, at 92.

30. Tocqueville observed that in America,

all parties are obliged to borrow, in their daily controversies, the ideas, and even the language, peculiar to judicial proceedings. . . The language of the law thus becomes, in some measure, a vulgar tongue; the spirit of the law, which is produced in the schools and courts of justice, gradually penetrates beyond their walls to the bosom of society.

ToCQUEVILLE, supra note 23, at 280 .

31. Grey, supra note 28 , at 11 .

32. Id. at 12 .

33. Id. at 43 .

Practical predictability of judicial decision can often be obtained by the framing of formal and objective bottom-level rules to govern decision. . . But rules of this sort have to be manufactured by arhitrary acts of human will; they cannot be deducted from the kind of high-lcvel abstract principles classical science sought to discover.

$I d$. at 43-44. This failure has much to do with the fact that legal science was not in fact, scientific. Wiecek observes that "[l]egal scientists were iguorant of real sciences, except for the evolutionary 
tension between the urgent need for law to address social and economic change and legal science's "indifference toward specific facts and circumstances of particular cases" ${ }^{34}$ became increasingly apparent, legal science came to seem unrealistic at best, and possibly nakedly pro-business. ${ }^{35} \mathrm{By}$ the end of the 1930s, progressives and legal realists had discredited the idea that law is objective and autonomous in favor of an understanding of law as embedded in and properly responsive to social conditions. ${ }^{36}$ But the potential social costs of legal science's abstraction were apparent almost from its inception. ${ }^{37}$

Henry James was among those who early recognized the liabilities of legal science. He also recognized, ahead of the fashion, that "[m]ost social relations are permeated with law." 38 Washington Square makes both of these points clear, and places them in the context of the clashing perspectives and practices of the postbellum period. In the novel, James charts the collision of four cultural vocabularies that simultaneously shaped and responded to

thought of Charles Darwin. . . Rather, they claimed absolute, objective, universal validity for their niethods and the results produced by those methods." WIECEK, supra note 23, at 91; see also Dimock, supra note 28, at 220, 225-28 ("Any knowledge derived from [logic] is propositionally derivative, parasitic on preassigned verbal entities. Such knowledge comes into being only by fiat, only by an arbitrary act of naming. Logic is thus conventional rather than natural.").

34. WIECEK, supra note 24, at 101 .

35. Both Wiecck and Grey argue that it is unlikely legal scientists self-consciously intended to serve their own economic interests. See Grey, supra note 28 , at 35 ; WIECEK, supra note 24 , at 11. Rather, legal science embodied the coolly seductive fantasy that, even in the absence of genume communal solidarity, and industrial society might nonethcless be hcld together by a structure of legal doctrine that, conceived in the pure spirit of science and possessed of its elegant rigor, transcends the ugly partisan struggles of politics, and at the same time defines the boundaries of the sovereign self in a way sufficiently practical to resolve real human disputes.

Grey, supra note 28 , at 53 .

36. See Neil Duxbury, Patterns of American Jurisprudence 32-64 (1995) (describing the legal realist response to legal formalism); Barbara H. Fried, The Progressive ASSAULT ON LAISSEZ-FAIRE 1-28 (1998) (describing the progressive critique of laissez-faire); HoRwiTz, supra note 27, at 33-63 (dcscribing the progressive and legal realist critique of freedom of contract). Of course, formalism persists in legal theory. See Thonias C. Grey, The New Formalism (Stanford Law Sch., Pub. Law \& Legal Series, Working Paper No. 4, Sept. 6, 1999), available at $\mathrm{http}: / / \mathrm{ssrn}$.com/abstract $=200732$.

37. Oliver Wendell Holmes, Jr. was an early critic, famously observing in his 1880 review of Langdell's book on contracts that "[t]he life of the law has not been logic; is has been experience," followed by a variety of progressive thinkers critical of legal science's formalism and Suprenie Court decisions like Lochner v. New York (1905). Oliver Wendell Holmes, JR., The COMmon LAW 1 (1881). On early resistance to legal science, see Horwitz, supra note 27; FriED, supra note 36; WIECEK, supra note 24 at 101.

38. Sarat \& Simon, supra note 2 at 14 . Sarat and Kearns have recently observed that "we come, in uncertain and contingent ways, to see ourselves as the law sees us; we participate in the construction of law's 'meanings' and its representations of us even as we internalize them, so much that our own purposes and understandings can no longer be extricatcd from those meanings." Austin Sarat \& Thomas R. Kearns, The Cultural Lives of Law, in LAW IN THE Domains of Culture 1, 7-8 (Austin Sarat \& Thomas R. Kearns cds., 1998). On the relationship between law and culture, see BINDER \& WEISBERG, supra note 7, at 462-539. 
postbellum social and economic conditions: the categorical abstraction of legal science; the conservative moralism of Victorian ideology, which had dominated the thought of the elite and bourgeoisie in the first half of the century and would persist well into the next; ${ }^{39}$ the free market individualism of classical economics; ${ }^{40}$ and the romantic idealism of the sentimental novel, associated with the growing (and increasingly literate) middle class, inexpensive printing techniques, and mass culture generally. ${ }^{41}$ James locates this collision within a house (in New York's Washington Square) and a family (the Slopers) but its effects within that family illuminate the consequences for American society generally.

The core themes of the novel (whether abstraction reveals or pervcrts truth; whether personal relationships can be insulated from social change; how to set standards by which conduct should be judged in new social contexts) are conceived by each of James's characters in terms of "rights," "duties," and "liberty." It quickly becomes clear, however, that these familiar and fundamentally legal concepts fail to order social relations because their meanings differ in each of the four vocabularies circulating in the novel. James does not take sides in this contest. Rather, he documents the "slippage" between legal and cultural aspirations and outcomes through the incompatible understandings of value, personal sincerity, and interpersonal obligation that

39. Daniel Walker Howe, Victorian Culture in America, in ViCTORIAN AMERICA 3 (Daniel Walker Howe ed., 1976).

40. C. B. Macpherson identifies the kernel of classical liberalism as the "conception of the individual as essentially the proprietor of his own person or capacities, owing nothing to society for them." C.B. MacPherson, The Political Theory of Possessive Individualism 3 (1962). In this scheme, the individual "is free inasmuch as he is proprietor of his person and capacities," and "[s]ociety consists of relations between proprietors. Political society becomes a calculated device for the protection of this property and for the maintenance of an orderly relation of exchange." Id. This maintenance was properly minimal-as Adam Smith (who published The Wealth of Nations in 1776) argued, natural laws of supply and demand would yield optimal results if freedom of exchange was unhindered. Following Smith, Ricardo and other classical economists insisted that competition, the "pursuit of individual advantage is admirably connected with the universal good of the whole." P. S. ATIYAH, The Rise and FAll of Freedom of Contract 316 (1985). By the nineteenth century, this conception had taken on the aspect of "a moral principle" to be "observed in social and political reform." Id. at 260 . "The whole essence of this form of individualism was that a man was left free to choose, but he paid the 'natural' penalty if he chose wrongly." Id. 273. In the late nineteenth century, Herbert Spencer and others would employ the logic of laissez-faire to combine classical liheralism with social Darwinism. See FrIED, supra note 36, at 29-31; see also P. Boller, American Thought in Transition: The Impact of Evolutionary Naturalism (1969); Jacob Viner, The Intellectual History of Laissez-faire, $3 \mathrm{~J}$. L. \& ECon. 45 (1960). But see Mark Francis, Herbert Spencer and the Myth of Laissez-faire, $39 \mathrm{~J}$. Hist. of IDEAs 2, 317-328 (1978).

41. See Ann Douglas, The Feminization of American Culture (1977); Karen Halttunen, Confidence Men and Painted Women: A Study of Middle-Class Culture in America, I830-1870 (1982); LAWREnCE W. LeVine, Highbrow/Lowbrow: The Emergence of Cultural Hierarchy in America (1988); Jane Tompkins, Sensational Designs: The Cultural Work of AmErican Fiction, 1790- 1860 (I985) 
emerge. ${ }^{42}$

In Washington Square, this slippage often manifests as irony-a disconnect between what is said and what is meant. Sometimes the irony is intended by the characters, who deploy it as a kind of shield as they navigate the unstable terrain of competing cultural values and assumptions. ${ }^{43}$ But in the collision of meanings in the text, unintended ironies also abound, often with pernicious results. These results suggest the relcvance of the collision of culturaI vocabularies James describes to legal discourse in the period. Reading the Supreme Court opinions of the Lochner era not just in terms of the formalism of legal science ${ }^{44}$ and the individualism of elassical economic theory, ${ }^{45}$ but also against the still robust discourse of Victorian morality and the lingering hold of romantic idealism in the sentimentalism of the period, helps bring the Court's (and other legal scholars') conflicted aspirations into relief. Recognizing the discursive instability in these legal texts facilitates a more nuanced understanding of law as culture. ${ }^{46}$

I begin this article by describing the plot and context of Washington

42. Mezey, supra note 3 , at 54 .

43. WAYNE C. Booth, A RHETORIC OF IRONy 5 (I974) (Intended ironies are "deliberately created by human beings to be heard or read and understood with some precision by other human beings; they are not mere openings, provided unconsciously, or accidental statements allowing the confirmed pursuer of ironies to read them as reflections against the author.").

44. “Formalism' describes legal theories that stress the importance of rationally uncontroversial reasoning in legal decision, whether from highly particular rules or quite abstract principles." Grey, supra note 28 , at 9.

45. This is the approach most legal historians have taken. See, e.g., WIECEK, supra note 24; Horwitz, supra note 27; Duncan Kennedy, Form and Substance in Private Law Adjudication, 89 HARV. L. REv. 1685 (1976). It is important to note here that Langdell and his disciples "did not regard public law, including constitutional law, as amenable to scientific study at all." Grey, supra note 28 , at 34 . Ncvertheless, Duncan Kcnnedy argues that the conflation of the private law meaning of "liberty" with the constitutional interpretation of liberty "integrated public and private law." Kennedy, supra, at I754; see also HoRwITZ, supra note 27, at 16 (arguing that the assumptions of classical legal orthodoxy bled into public law); WIECEK, supra note 24, at 123.

46. Binder and Weisberg observe that the cultural studies movement has blurred the boundaries between the humanities and the social sciences by viewing the phonomena studied by political scientists, sociologists, economists, and historians as social 'texts' available for interpretation and critieism. It has also extended the domain of ethnographic method from the study of traditional non-Western societies to modern Western societies, thereby both expanding anthropology and raising critical questions about the assumptions that have confined it in the past. A closely aligned movement in literary studies, 'the New Historicism,' has in essence madc literary criticism an instrument of the ethnography or archaeology of modernity by treating literary texts as cultural artifacts.

But Binder and Weisbcrg's proposal "is not just that legal phenomena be viewed as cultural artifacts or 'social texts,' like any others. It is that legal forms and legal processes play a compositional role in modern culture - that cultural criticism must attend to the legal dimension of culture or remain superficial." BINDER \& WEISBERG, supra note 7, at 463-464. On New Historicism, see Brook Thomas, New Historicism and Other Old Fashioned Topics (1991); The New Historicism (H. Aram Veeser ed., 1989). 
Square. I then analyze the competing vocabularies with which James identifies the four main characters of the novel, beginning with the discourse of legal science, and moving through James's representations of sentimentalism, free market individualism, and finally Victorian conservatism. The incomensurable versions of rights, duties, liberty and value that emerge from these vocabularies undermine personal expectations and interpersonal relationships in the novel in ways that reflect the social upheaval of the period. In sections three and four I argue that James's recognition of irony in the collision of these competing vocabularies helps illuminate both the influence of legal concepts on the broader culture and the impact of cultural discursive instability within legal discourse. Finally, I propose that James's representation of the multiple vocabularies circulating in postbellum law and culture discloses the relevance and utility of fiction, particularly at moments of legal and cultural change.

\section{The Context of the Novel}

Henry James, Jr. was born in New York City in I843. ${ }^{47}$ His Irish paternal grandfather had immigrated to the United States in 1789 and made a fortune in business in Albany, New York. This wealth afforded James's father, Henry Sr., a life of the mind: he briefly attended both law school and theological seminary but was ultimately a self-styled intellectual and philosopher. ${ }^{48}$ During Henry Jr.'s youth, the Jameses lived for Iong periods in Europe, and as a result his education was as cosmopolitan as it was "unsystematic," leaving him, perhaps above all else, with an acute sense of culture - the institutions and traditions that contribute to national and personal identity. ${ }^{49}$

This sensitivity to culture adds complexity to the realism of James's fiction. ${ }^{50}$ American literary realism, in its many manifestations, "grew out of

47. James is widely recognized as one of the great American writers. James was prolific over more than three decades, publishing novels, stories, travelogues, memoirs, reviews and plays. Washington Square was written relatively early in his career, but just as he gained full control of his powers; he would publish Portrait of a Lady, considered his first great novel, the following year. 2 The Norton Anthology of American Literature 274-75 (W.W. Norton \& Company ed., 4th ed. 1994).

48. Leon Edel, Henry James: The Untried Years, I843-1870, $26-37$ (1953). Henry Sr. counted many leading nineteenth century writers and intellectuals among his friends, including Ralph Waldo Emerson and Edwin Godkin, founder of The Nation, relationships which informed and enriched his children's lives as well. James's older brother, William became one of the most important philosophers of his day. Among his important works are The Principles of Psychology (1890) and Pragmatism (1907).

49. See The Norton Anthology of American Literature, supra note 47, at 274.

50. American literary realism dominated the fiction of the postbellum years. James was among the diverse American writers, including Mark Twain, W. D. Howells, Stephen Crane, Frank Norris and Theodore Dreiser, who believed that literature could and should represent the reality of lived experience, as they knew it and as it was newly understood by the emerging social sciences. American literary realism was also informed by the example of Continental writers responding to industrialization and social Darwinism. The NorTon ANThOLOGY of AmERICAN 
the bewilderment, and thrived on the simple grimness, of a generation suddenly brought face to face with the pervasive materialism of industrial capitalism." 1 Its primary subjects were the poverty and brutality of industrial work, the lonely anonymity of urban life, and the psychological effects of social and economic upheaval. With his fellow realists, James thought the "only reason for the existence of a novel is that it does attempt to represent life." Indeed, in its "truth of detail," James analogized the novel to history. ${ }^{52}$ Still, for James, realism was most interesting in its approach to "the complexities of consciousness." ${ }^{53}$ And for James, consciousness was largely the creature of culture.

James's fiction invites the cultural study of Iaw in part because James himself was intent on representing the social structures that informed what he called "psychological reasons." ${ }^{54}$ Like many of James's novels of the 1880 s, the drama of Washington Square "depends on the range and subtlety of Jamcs's presentation of social relationships, with all that that implies of tone, habits of deference, poise, conscious civility, calculated decorum: all those elements, in short, in which certain lives are given definitive shape and to which they can become forfeit." 55 But Washington Square is particularly provocative for our purposes because it is one of the rare James novels set almost entirely on American soil, and concerned exclusively with American culture. ${ }^{56}$

Literature, supra note 47, at 3-7; see also Alfred Kazin, On Native Grounds: An Interpretation of Modern American Prose Literature 3-51 (1942); Eric J. Sundquist, The Country of the Blue, in AMERICAN REALISM: NEw EsSAYS 3 (Eric J. Sundquist ed., 1982).

51. KAZIN, supra note 51 , at 15 .

52. Henry James, The Art of Fiction, in Tales of Henry James 346, 347, 352 (Christof Wegelin \& Henry B. Wonhan eds. 1984). His advice to would-bc writers was: "Try to be somcone on whom nothing is lost!" Id. at 352.

53. KAZIN, supra note 51 , at 47.

54. "There are few things more exciting to me, in short, than a psychological reason." James, supra note 52, at 390 . In recent years, literary criticism, much like the cultural study of law, has recognized that

the textual production of reality does not occur in a linguistic vacuum; neither is it politically innocent, of course, but always charged by ideology - those unspoken collective understandings, conventions, stories, and cultural practices that uphold systems of social power. These approaches situated rcalistic texts within a wider field of what has been called 'discursive practices.'

See Amy Kaplan, The Social Construction of American Realism 6 (1988). Kaplan further argues that "[r]ealists do more than passively record the world outside; they activcly crcate and criticize the meanings, representations, and ideologies of their own changing culture." Id. at 7.

55. John Lucas, Washington Square, in ThE AIR OF REALITY: NEW EsSAYS ON HENRY JAMES 36, 38 (John Goode ed., 1972). For Lucas, "[i]t is the ordinariness which is so extraordinary about Washington Square." Id. at 59. L. C. Knights observes that James "is concerned with the subtler forms of pressure, manipulation, or victimization, whether by onc person acting on another, more or less consciously, or by a social group whose assumptions and attitudes, without much deliberate intention, crush life and spontaneity." L. C. Knights, Henry James and Human Liberty, 83 SEWANEE REv. 17 (Winter 1975).

56. The Bostonians (1886) shares this peculiarity and is, likc Washington Square, 
The kernel of Washington Square appears in James's notebooks in a February, 1879 entry as a story told by his close friend, Fanny Kemble. Kemble's brother, a beautiful young soldier "without a penny to his name" undertakes the suit of a "dull plain, common-place girl" who stands to inherit a "handsome fortune." The girl's father "justly" suspects that Kemble's brother is "very luxurious and selfish" and threatens to disinherit his daughter if she marries him. But the girl chooses love and the young man prolongs the engagement until he is convinced the father will not relent. Then he breaks the girl's heart. When he returns more than ten years later, the girl has inherited her fortune and refused all other suitors but refuses also to marry him. Though she still cares for him, "it was too late." 57

In the translation of this anecdote to the novel, James relocates the action from England to New York and transforms the father from the Master of King's College, Cambridge to a medical doctor he calls Austin Sloper. ${ }^{58}$ Indeed, the most significant change from the anecdote to the novel is James's invention of Dr. Sloper and the elaboration of the relationships shaped by his particularly "scientific" authority. Sloper's empirical method extends to his family and he treats the first love affair of his daughter, Catherine, as an opportunity to test his judgments of her (he has until this point found her disappointing) and of her beautiful young suitor Morris, a stranger Sloper believes he knows as a "type." 59 Rather than protectively forbidding a match of which he disapproves-thereby intolerably "rendering [Morris] more interesting" to his daughter ${ }^{60}$ - Sloper ostensibly leaves Catherine at "[her] liberty" to choose. ${ }^{61}$ But his version of respecting her liberty does not preclude him from visiting his disapprobation upon her. (The experiment, after all, is a test not of her filial devotion, but of whether Sloper has judged her character

particularly interested in sets of conflicts within Amcrican culture. The literary critic lan Bell has argued that "Washington Square is about history, about the ways in which economics and commercial practices structure human relationships, and about the ways in which history may be represented in fictional forms." Ian F. A. Bell, Washington Square: Strles of Money 23 (1993).

57. The Complete Notebooks of Henry James 11-12 (Leon Edel \& Lyall H. Powers eds., 1987).

58. James makes a number of additional alterations. In the novel, for example, the beautiful young man may once have been in the Navy, and has already squandered a small fortune of his own before beginning his suit of the girl. James's notebook cntry makes brief mention of another sister, who attempts to bring the jilted heiress and her brother together the seeond time, an attempt Kemble considers "an ignoble speculation." Id. at 11. This sister becoines Mrs. Penniman, the meddling aunt in the novcl, while Kcmble herself becoines Mrs. Almond, thc "comely, comfortable, reasonable" aunt. JAMES, supra note 13, at 10. Kemble's admonition that the girl not marry hcr brother, however, worded so similarly to Dr. Sloper's, suggests that some of Kemble's traits have become the doctor's as well. On the friendship of Kemble and James, sce EDEL, supra note 48 , at $351-52$.

59. JAMES, supra note 13 , at 87 .

60. Id. at 70 .

61. Id. at 68-69. 
and social worth rightly.) For Catherine, this "liberty" amounts to an all but impossible choice between Morris, the first man who has made her feel loved, and not merely the love of the father she has admired and adored all her life, but the sense of her own identity in which she is, above all, a good and dutiful daughter.

Catherine's acceptance of Morris's proposal, however, does not end the experiment for Sloper. Once they are engaged, Sloper threatens to disinherit Catherine if she goes through with the marriage. Sloper is already certain that Morris is after Catherine's money by the time he makes the threat (a fact he has determined by interviewing Morris's sister, upon whom Morris "sponges"). ${ }^{62}$ What interests him is whether Morris is, as Sloper suspects, the type who will abandon Catherine despite the modest fortune she will still inherit from her mother (a detail James has added to the original anecdote). For Sloper, the "positive excitement" of the experiment lies in determining whether his observations have yielded correct judgments. ${ }^{63}$ Or at least, that is how it starts.

In Washington Square, the unscrupulous suitor's hesitation to marry the girl for her own modest fortune with the hope that her father will relent drags on for more than a year. Sloper takes Catherine to Europe with the ambition that she will forget Morris, and Morris encourages her to go with the ambition that she will change Sloper's mind. Neither outcome is achieved, but her father's lack of sympathy finally convinces Catherine to burn her bridges with him. "I will never ask him for anything again, or expect anything from him,",64 she tells Morris upon her return. Morris promptly decides to give her up, first trying to convince the girl's aunt to break the news and eventually calling off the engagement by letter. What happens next surprises the doctor. Catherine reports that it is she who has ended the engagement and goes on about her life in her father's house apparently "just as usual." 65 Catherine and her father spend the rest of his life (more than twenty years) together quietly in his house on Washington Square with no sign of Morris, but the doctor's unexpressed surprise evolves into an erroneous suspicion that Catherine plans to marry Morris after he is dead. When she refuses, on principle, to promise not to marry Morris shortly before the doctor's death, ${ }^{66}$ Sloper makes arrangements to disinherit her. After his will is read, Catherine says of her disinheritancewithout irony - "I like it very much." "67 Morris returns and Catherine rejects him.

62. Id. at 89 .

63. Id. at 129 .

64. Id. at 161 .

65. Id. at 120 .

66. We are told that "[s]he had been so humble in her youth that she could now afford to have a little pride, and there was something in this request, and in hor father's thinking himself to free to make it, that seemed an injury to her dignity." $I d$. at 206.

67. Id. at 207 
James's biography in the late 1870 s offers a number of potential inducements to the invention of Dr. Sloper. His medically trained older brother William, with whom James had a close but complicated relationship, continued to be critical of James's work, despite his growing celebrity and success. ${ }^{68}$ Their father, the eccentric Henry Sr., who had tested his own theories on his children, was nearing the end of his life. ${ }^{69}$ And James had just written a book about one of his literary fathers, Nathaniel Hawthorne, which received negative reviews from American critics James had expected the book to please. ${ }^{70}$ James's interest in the motives and effects of a character like Dr. Sloper-a man from the generation of his father and many of his reviewers - can and should be understood in terms of these potential causes, at least insofar as they encouraged him, rather unexpectedly, to reexamine American identity in 1879 .

By 1879, James had taken up permanent residence in England, and his fictional characters had long inhabited the cosmopolitan scenes of his childhood and of his adult life spent mainly between England and the Continent. Compared with The Americans and Portrait of a Lady, the books James wrote directly before and after Washington Square, the novel's almost claustrophobic circumscription to four relatively unsympathetic persons in a handful of New York rooms is striking. ${ }^{71}$ 1ts self-conscious narrowness reflects Jamcs's determination to write an American book, about Americans. ${ }^{72}$ And while James's interest had begun to turn to female protagonists, Catherine Sloper is an unusual Jamesian heroine: she is not beautiful, she is not brilliant, and she is not exactly frustrated. ${ }^{73}$ Nor is her type necessarily American (her model is, after all, an English girl). But her plight-struggling to maintain Victorian expectations of personal integrity against a swirling tide of economic opportunism, sentimental idealism, and legal formalism-is uniquely American, and registers the contending forces in American culture in the postbellum era with particular clarity.

68. EDEL, supra note 48, at 383-86. Oliver Wendell Holmes, Sr., a celebrated physician, may also have been a model for Sloper.

69. Henry James, Sr. would pass away in 1882.

70. EDEL, supra note 48, at 386-91. In a letter dated March 31, 1880 James wrote to his friend Charles Eliot Norton (editor of the North American Review and Harvard History professor) "poor little Hawthorne. . .appears to have had the fate of creating a very big tempest in a very small tea-pot. . . . It seems to me like the clucking of a brood of prairie-hens. My critics, either literally or essentially, seem to me all to have been of the hen-sex." 2 Henry James LeTters, I 875-I 883280 (Leon Edel ed., 1975).

71. Contemporary reviewers remarked on this nartowness widely. HenRY JAmES: ThE Contemporary Reviews 10 I-17 (Kevin J. Haycs ed., 1996).

72. He described it as "a tale purely American" in a January 31,1880 letter to William Dean Howells, the most important promoter of American literary realism in the late nineteenth century, who was a successful novelist as well as the editor of the Atlantic Monthly. HENRY JAMEs LETTERS, supra note 70 , at 268.

73. EDEL, supra note 48, at 392 (on James's interest turning to female heroines in the late 1870s), 
It was just as he began to write Washington Square that James famously lamented the poverty of American culture from the standpoint of a novelist. ${ }^{74}$ In the absence of the rich and largely stable traditions, manners, architecture, and other material culture that anchor identity for his European characters (and, by negative association, his American characters) in other novels, James aligns the identities of his Americans in Washington Square with the competing vocabularies, or ways of talking about the world, to which they subscribe. But ways of talking about the world unconnected to long-standing traditions offer considerably less stability than ruins or country seats.

"Americanness" and the law are inextricably linked through James's biography. Soon after the James family returned to the United States, the two youngest brothers joined the Union army, and James and William found themselves at Harvard. Possibly prevented from enlisting by an injury to his back, James entered Harvard Law School in September 1862, at the age of nineteen. ${ }^{75}$ There, "he had a classroom filled with Americans to study at first hand. For the first time he found himself among his young contemporaries in his native land."76 James would leave after a year to begin writing full time and he is reported not to have "studied his law books with any assiduity," but he did faithfully attend lectures. ${ }^{77}$ In addition to studying his classmates, James had occasion to closely observe his professors, Theophilus Parsons, Emory

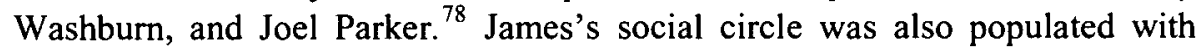
lawyers and legal academics. In the 1860s, William and James enjoyed close

74. In the same notebook entry in which he recorded the kernel of the story of Washington Square, James wrote a version of the list of things lacking in America — "a country . . . without a picturesque peasantry, without palaces or castles . . . or ruins, without a literature, . . . without political society, ... . without fox-hunting or country gentlemen"-which appeared later that year in his book on Hawthorne and provoked American critics. COMPLETE NOTEBOOKS OF HeNRY JAMES, supra note 57, at 12 . The thinness of place and eulture reviewers observed in Washington Square bears out James's sense of the poverty of American material. Indeed, in the same lctter in which be answers William Dean Howell's censure for describing America as lacking the prerequisites of great literature, James wrote that composing Washington Square "made me feel acutely the want of the "paraphernalia." Letter from Henry James to William Deans Howells (Jan. 31, 1880), in HENRY JAMES LeTTERS, supra note 70.

75. Edel writes that for James law was "the one field that seemed eininently "practical"" though Edel also suggests that law may simply have offered "the avenue of least resistance" for a young man "who asked only to be just "literary." EDEL, supra note 48, at 193.

76. Id. at 196.

77. Id. at $198,196$.

78. James offers amusing descriptions of these men in his memoirs. HENRY JAMES, Notes of A Son And Brother 347, 348, 353-54 (1914). Theophilus Parsons had published the influential treatise The Law of Contracts in 1855. The Law of Contracts established an "objective theory that would thereafter dominate American law." MORTON Horwitz, THE Transformation OF AMERICAN LAw, I780-I860 197 (1977). Joel Parker had been the Chief Justice of the New Hampshire Supreme Court before joining the Harvard law faculty, and Emory Washburn had been the governor of Massachusetts. William P. LaPiana, Logic \& Experience: The Origin of Modern American Legal Education 8 (1994). 
friendships with Oliver Wendell Holmes, $\mathrm{Jr}^{79}$ and John Chipman Gray. ${ }^{80}$ James also knew William Wetmore Story, Joseph Story's son, and later wrote his biography. ${ }^{81}$

The particular form of "liberal" empiricism with which he identifies Dr. Sloper-the "realm of the practical," "touched by the light of science" 82 -was thus familiar to James through his family's connections and his experience as a student at Harvard Law School. This version of empiricism posits that scientific observation can yield inductive generalizations that are axiomatic. In this method,

observations inductively supporting a generalization transfer their confirming power undiminished to any proposition that logically flows from that generalization. At the same time, the derived proposition transfers its own independent inductive support back to the generalization, since the logical derivation has shown it to be within generalization's scope. The arrangement of inductively derived generalizations into a deductive system thus vastly extends our use of the resources of experience, by spreading the confirming force of observations undiminished even through long and difficult chains of deductive inference. ${ }^{83}$

The result is a science based in experience which generates formal laws representing immutable and autonomous truths. Nineteenth century applications of this methodology (seeking general laws in aggregates of observed particulars) to the social realm manifested as utilitarianism, classical economics, and Social Darwinism as well as legal science.

In the antebellum period, legal thinkers had understood the American legal system to be comprised of "qualitatively distinct" legal relationships (between private individuals, between the individual and the state, between states and the federal government, between legislatures and courts) operating according to "qualitatively distinct analytic principles." 84 In contrast,

79. Mark DeWolfe Howe, Justice Oliver Wendell Holmes: The Shaping Years, I841-1870 201 (1957); EDEL, supra note 48. William would continue to be closc to both men throughout his life. See Louis Menand, The Metaphysical Club (2001).

80. EDEL, supra note 48, at 229. Gray, like Holmcs, was a critic of legal science. WIEcEK, supra note 24, at 101; see also Stephen A. Siegel, John Chipman Gray and the Moral Basis of Classical Legal Thought, 86 Iowa L. REv. I 1513 (2001).

81. William Story played an important part in the construction of "a unified body of contract law" in the mid-nineteenth century. WIECEK, supra note 24 , at 103. James published his biography of Story, who moved to Europe and became an artist, in 1903. See Joseph Hynes, The Transparent Shroud: Henry James and William Story, 46 Am. LiTERATURE 506 (1975).

82. JAMES, supra note 13 , at 5 . We are told that Sloper's purpose in becoining a physician "had not been preponderantly to make money-it had been rather to learn something and to do something. To learn something interesting, and to do something useful . . ." Id. at 7 .

83. Grey, supra note 28 , at 19 . This brand of liberalism was empiricist in the sense that its methods were inductive rather than deductive, but in its categorical eonclusions, it tended toward formalism.

84. Duncan Kennedy, Toward an Historical Understanding of Legal Consciousness: The 
postbellum legal science understood these relationships as "particular instances of a single general legal relation," making possible "the application of a single, distinctly legal, analytic apparatus" to all legal questions. ${ }^{85}$ The great appeal of legal science was certainty: “A few basic top-level categories and principles formed a conceptually ordered system above a large number of bottom-level rules" and when "a new case arose to which no existing rule applied, it could be categorized and the correct rule for it could be inferred by use of the general concepts and principles; the rule could then be applied to the facts to dietate the unique correct decision in the case." 86

The categorical reasoning of legal science, which held that once "problems could be assigned to their proper conceptual pigeonholes, solutions would predictably follow" distinguishes Dr. Sloper's personal as well as medical authority in Washington Square. ${ }^{88}$ "He had passed his life in estimating people (it was part of the medical trade), and in nineteen cases out of twenty he was right." 89 Therefore Sloper has little doubt of his conclusion, based on his long experience "dividing peoplc into classes, into types," that Morris is the wrong "type" for Catherine. ${ }^{90}$ Indeed, Sloper is insistent throughout the novel that his objection to Morris is not personal, but categorical. "Your absence of means, of a profession, of visible resources or prospects," he explains to Morris early on, "places you in a category from which it would be imprudent for me to select a husband for my daughter." W1 When Morris responds that Catherine marries "an individual," not a "category," and moreover that he has other virtues that counter the accident of his type, Sloper remains unmoved. "There is nothing against you but an accident, if you will; but with my thirty years' medical practice, I have seen

Case of Classical Legal Thought in America, 1850-1940, 3 RES. L. \& SoC. 4 (1980).

85. Id. at 5.

86. Grey, supra note 28 , at 11 . In this way, classical lcgal thought appeared to permit the resolution of the basic institutional conflicts between populistic legislatures and private businesses, between legislatures and courts over the legitimacy and extent of judicial review, and between statc and federal governments struggling for rcgulatory jurisdiction. At the level of ideas, it mediated the contradictions betwcen natural rights theories and legal positivism, and bctween the democratic theory of legislative supremacy and the Classical economic prescriptions about the optimal role of the state in the economy.

Kenncdy, supra note 84 , at 9.

87. WIECEK, supra note 24 , at 90 .

88. John Austin suggests the analogy of law and medicine: "Law, like medicine, is a preventative or remedy of evil: and, if the world were free from evil, the notion and the name would be unknown." John Austin, The Province of Jurisprudence Determined 64 (David Campbell \& Philip Thomas eds., 1998) (emphasis in original).

89. JAMES, supra note 13 , at 79 .

90. Id. at 87.

91. Id. at 74-75. 
that accidents have far-reaching consequences.",92

\section{II}

\section{COMPETING DISCOURSES IN WASHINGTON SQUARE}

\section{A. Legal Science}

Austin Sloper may be a medical doctor, but we never see him in that light in the novel. The only house call we see him make is his trip to interrogate Morris's sister, Mrs. Montgomery-a visit undertaken not to make a diagnosis but to confirm a principle. His refusal to privilege Catherine's happiness over the far-reaching consequences of benefiting someone of Morris's type reflects the utilitarian strain in liberal empiricism generally but also in legal science more particularly. Indeed, Sloper's social identity in the novel is very much that of a judge, and in the exercise of his personal authority, Sloper employs the logic of legal science. ${ }^{93}$

John Austin, the first professor of Jurisprudence at the University of London, was an early proponent of an empirical science of law. ${ }^{94}$ His influential Province of Jurisprudence Determined (1832) combined "a determinedly empirical approach to law with a view that it could be analyzed by means of traditional logic." 95 Province of Jurisprudence could be found in the Harvard law library as early as 1841 but Austin's theory rose to prominence in American legal academic circles in 1862, the year James entered law school at Harvard. ${ }^{96}$ The well-documented influence of Austin on John Chipman

92. Id. at $75-76$.

93. My reading of Dr. Sloper refines the dominant view in literary criticism that James offers Sloper as an "archetype (not that Janes would deploy the word) of the bourgeois temperament which sustains a view of the world as a market-plaee for eommodities by a balaneed, rational discourse authorized by the types of science and the precepts of mathematics." lan F. A. Bell, Money, History and Writing in Henry James: Assaying Washington Square, in HENRY James: Fiction As History (Ian F. A. Bell, ed.) 11, 34 (1984). Bell and many who have followed him mistakenly conflate Sloper's liberalism with an acceptance of the logic of commodification, much the way legal science has been conflated with laissez-faire in soine legal histories. See, e.g., Greg W. Zacharias, Henry James' Style in Washington Square, 18 STUdies IN AMERICAN Fiction 208 (1990). But see Millicent Bell, Washington Square: Style as Subject, 83 SewaneE Rev. I9, 28 (Winter 1975) (recognizing that Sloper "expects that experience can be made to conform to his formal expectations . . . like a certain kind of classic garden plan").

94. Austin, supra note 88, at ix. Austin aspired to develop a science of jurisprudence modeled on the politieal economy of David Rieardo and James Mill. Austin was an early disciple of Jeremy Bentham, the father of utilitariamism and James Mill's son, John Stuart Mill was among Austin's students. W. L. Morison, John Austin I (1982).

95. MORISON, supra note 94, at 141. In this way, the "distinctive character of the philosophy which Austin sought to apply to law is its combination of empiricism-the view that reality consists of observed occurrences-and formalism-the view that our language represents patterns of occurrences in their true logical forms." Id. at 5.

96. Austin, supra note 88, at ix. Province of Jurisprudence first appeared on the reading list for the first year curriculum at Harvard Law School in 1863-64. 
Gray, ${ }^{97}$ who graduated from Harvard Law in 1861, and Oliver Wendell Holmes, Jr., ${ }^{98}$ who entered Harvard Law in 1864, strongly suggests that James would have been familiar with Austin's theory. James certainly would have been aware of the ascendancy of legal science at Harvard Law School in the $1870 \mathrm{~s} .{ }^{99}$ Austin was only one influence on postbellum American legal science, and American legal science diverged from Austin's narrow definition of positive law. ${ }^{100}$ But American legal orthodoxy shared Austin's insistence on the separation of law from morality and the formalism of his conceptions of rights and duties. ${ }^{101}$

In his defense of utility, rather than "moral sense," as the foundation of positive law, Austin observed that the "respective moral sentiments of different ages and nations, and of different men in the same age and nation, have differed to infinity." 102 Moreover, there is no way to distinguish authentic moral sentiments-sentiments which reflect divine moral law-from sentiments "which are factitious, or begotten in the way of association" in any given instance. ${ }^{103}$ It follows that if moral sense fails as "a common test of human conduct," basing judgments on a general, testable theory is preferable. ${ }^{104}$ Against the complaint that the theory of general utility is insensitive to individual suffering, Austin counters that motives like benevolence, "though certainly unselfish and generally esteemed good motives, may, when narrowed in their aims, or directed by a perverted understanding, lead to actions most pernicious." ${ }^{105}$ The example that Austin offers bears particular relevance to Sloper's apparent indifference to Catherine's unhappiness: "the affection for children, and the consequent desire of pushing or advancing them in the world (a species of narrow benevolence), is with many persons more apt to lead to

97. MOR1SON, supra note 94 , at 160 .

98. "The influence on Holmes of Austin's analytical exposition of law was surely no less than was Maine's historical emphasis. The Austinian strain in Holmes's thought was vigorous and persistent." Mark DeWolfe Howe, Justice Oliver Wendell Holmes: The Shaping Years, 1841-1870 194 (1957). See generally H.L. Pohlman, Justice Oliver Wendell Holmes \& UTILITARIAN JURISPRUDENCE (1984).

99. On the public nature of the ascendancy of legal science at Harvard Law School, see LAPIANA, supra note 78, at 12-14 (1994). John Chipman Gray became a professor at Harvard Law School in 1875 .

100. LaPiANA, supra note 78, at 122-124. ("Langdell had absorbed much of the language of Austinian positivism. He also absorbed its concepts.").

101. See Grey, supra note 28 , at 15. ("Considerations of justice and convenience were relevant, but only insofar as they were embodied in principles-abstract yet precise norms that were consistent with other fundamental principles of the system. To let considerations of acceptability directly justify a bottom-level rule or individual decision would violate the requirement of conceptual order, on which the universal formality and completeness of the system depended.").

102. Austin, supra note 88 , at 65,73 .

103. Id. at 72 .

104. Id. at 74 (emphasis in original).

105. Id. at 81 . One of the effects of the methodology of legal science was the dissociation of considerations of justice or faimess from correct legal outcomes. Kennedy, supra note 84, at 13 
acts contrary to the public good than any purely selfish motive."106 Hence Sloper's position that even if Morris might make Catherine happy, allowing a mercenary fortune-seeker to prevail is clearly prohibitively disruptive to the social order. At the moment at which Sloper's indifference to Catherine's suffering seems most "cold-blooded," he compares himself to "a geometrical proposition." 107 For Sloper, as for Austin, science and logic treat "not that which ought to be but that which is." 108

Sloper's sense of the disutility of moral sense in arriving at correct judgments is made clear when he asks his sister Lavinia Penniman, who has just moved in with him and his motherless daughter, to " $[t]$ ry and make a clever woman" out of Catherine. Penniman asks, "Do you think it is better to be clever than to be good?" and he responds, "You are good for nothing unless you are clever . . I I don't want to have to compare her to good bread and buttcr." Catherine will not be "any the less virtuous," he concludes, "for not being a fool." 109 Sloper also agrees with Austin that law (which for Austin is composed of commands and sanctions ${ }^{110}$ ) is an effective means of education-that consequences are instructive. ${ }^{11}$ When it is suggested that Catherinc will not be capable of seeing Morris's "vulgar nature," Sloper determines to "present her with a pair of spectacles" in the form of his threat of disinheritance (which he correctly believes will unmask Morris's true motives). ${ }^{112}$ Even when it becomes clear that Catherine has been "cruelly jilted," 113 Sloper has no sympathy:

Doctor Sloper had his theory, and he rarely altered his theories. The marriagc would have been an abominable one, and the girl had had a blessed escape. She was not to be pitied for that, and to pretend to condole her would have been to make concessions to the idea that she had ever had a right to think of Morris. ${ }^{114}$

106. Austin, supra note 88 , at 81 .

107. JAMES, supra note 13, at 128. Austin had argued for the "geometric method in law and ethics on the ground that its impersonal certamty could fortify existing institutions against popular unrest." Grey, supra note 28, at 33. Sloper's last name, invoking the geometrical precision to which legal science aspired, further supports the connection between James's character and Austin and legal science more generally. See generally M.H. Hoeflich, Law \& Geometry: Legal Science from Leibniz to Langdell, 30 AM. J. LEGAL HIST. 95 (1986).

108. John Chipman Gray, The Nature and Sources of the Law 94 (Roland Gray, ed., $2 \mathrm{~d}$ ed., 1921) (quoted in LaPiana, supra note 78, at 125). "Taking an Austinian approach, in the light of its gcneral features, involves rejecting special imperative or 'ought' propositions which do not figure in traditional logic." MORISON, supra note 94, at 5 . In other words, for Sloper, as for Austin, how a father ought to treat his daughter's feelings has no place in determining the correct course of action.

109. JAMES, supra note 13 , at 12.

110. MORISON, supra note 94, at 65.

111. See Austin, supra note 88 , at xiv, 50-58.

112. JAMES, supra note 13 , at 49 .

113. Id. at 198 .

114. Id. at 198. 
Sloper's theory admits no exceptions.

On Austin's account, laws are properly understood as "commands" or "significations of desire" imposed on "political inferiors" by "political superiors" which expose the inferiors to sanctions if they do not comply. ${ }^{115}$ "Command and duty are, therefore, correlative terms . . . wherever a duty lies, a command has been signified; and whenever a command is signified, a duty is imposed." 116 Tellingly, "duty" and "obligation" are synonymous for Austin. No legally recognizable duty exists, either between political superiors and inferiors or among those inferiors, other than obligations expressly associated with commands. Such a narrow conception of duty resembles legal science's treatment of contracts, in which parties have no duties to one another other than those expressly articulated in the contract itself, regardless of a party's reliance, a party's failure to disclose, or any other apparently unfair outcome. ${ }^{117}$ Rights, in Austin's scheme, are similarly constricted. For Austin, a "right arises by imposition of a corresponding duty" 118 and it only arises if a law "hold[s] out a reward as an inducement to do some act." 119 In this way, rights are secondary to the imperatives that create them ${ }^{120}$ and liberty is negative-it is freedom from "legal obligation." 121 Thus, when Sloper leaves Catherine at her "liberty" "122 to see Morris, despite his disapproval, Sloper is merely refraining from issuing a command. There is nothing positive about this freedom, and it corresponds to legal orthodoxy's "negative" concept of liberty. ${ }^{123}$

The enormous gulf between Sloper's formal and constricted view of rights, duties and liberty and Catherine's far more expansive notion of filial obligation accounts for the crucial rupture between them in the novel. Sloper does not forbid Catherine, who is old enough at 22 to be her own mistress, ${ }^{124}$ from marrying Morris, but he does imply a command by articulating a sanction: if you marry Morris, the cost will be disinheritance. The difference is lost on

115. AusT1N, supra note 88 , at 11 .

116. Id. at 12 .

117. ATIYAH, supra note 40 , at 404 .

118. MoRISON, supra note 94 , at 75.

119. AUSTIN, supra note 88, at 13.

120. Austin, supra note 88 , at 13 .

121. Austin, supra note 88, at 191.

122. JAMES, supra note 13 , at 51 . We are told that the "doctor had a great idea of being largely just: He wished to leave his daughter her liberty, and interfere only when the danger should be proved." Id.

123. The basic condition for the exercise of individual will was liberty, which classical lawyers understood in the sense that lsaiah Berlin has deseribed as 'negative liberty.' Liberty in this sense required restraints on the state's power to assure that the individual would not be oppressed by its authority. Positive liberty, providing an active role to a person as a member of society exercising civic responsibility together with others, was alien to the classical mind.

WIECEK, supra note 24 , at 10.

124. JAMES, supra note 13 , at 73 . 
Catherine, who understands her father's disapproval to mean that her engagement violates his wishes and mistakes his determination to leave the choice up to her as conferring upon her a positive liberty. Thus when she finally determines to marry Morris, "it seemed to her that she had no right to enjoy [Sloper's] protection. It was on her conscience that she ought to live under his roof only so long as she conformed to his wisdom." 125 But when she presents this idea to Sloper, he expresses his displeasure with the devastating judgment that her "idea is in very bad taste." 126 Sloper's invocation of "bad taste" here is a rejection of Catherine's application of moral sense to the exercise of his authority. He believes he has done his "duty" by Catherine with "exemplary zeal" "127 because his sense of his duty to her is entirely confined to the consistent application of his scientific judgment. ${ }^{128} \mathrm{He}$ does not consider it his duty to consult her feelings, or even, for that matter, to love her. ${ }^{129}$

Sloper can be so certain of his judgments in part because value is fixed and knowable for him; things are what they are and they don't change. He "knew his own value," 130 for example, and his "local celebrity" as both a doctor and a "clever man"131 is a reflection of that value, not its source. The "positive excitement"132 of his experiment with Catherine lies not in the possibility that she will change, but in finally determining her value to him as a daughter. In this way, Sloper's experiment hinges on a conception of intrinsic and immutable value shared with postbellum legal science and inherited from classical economics in which "objects have a "natural' value" which their exchange value will approximate. ${ }^{133}$ In other words, Catherine's value is fixed

125. Id. at 134. Sloper's own behavior at this point in the novel goes a long way to justify her conviction. Even though they live in the same house, her "father never looked at her, never spoke to her" and, we are told, "rather enjoyed having to be so disagreeable." Id. at 135.

126. Id. at $137-38$.

127. Id. at 15 .

128. Of course, both Austin and American legal seientists, like Langdell, recognized tbat there were "other sorts of duties; "domestic or family relations give rise to a numerous class of duties.' Such duties, however, are moral rather than legal and are not enforced by the courts." LAPIANA, supra note 78, at 122. Nevertheless Sloper has clearly adopted Austm's view that "the whole of our conduct should be guided by utility." Austin, supra note 88, at 32-33.

129. We are told at the beginning of the novel that Catherine's deepest desire was to please [Sloper], and her conception of happiness was to know that she had succeeded in pleasing him. She had never succeeded beyond a ccrtain point. Though, on the whole, he was very kind to her, she was perfeetly aware of this, and to go beyond the point in question seemed to her really something to live for.

JAMES, supra note 13, at 14.

130. JAMES, supra note 13 , at 14 .

131. Id. at 6 .

132. Id. at 129.

133. FrIED, supra note 36 , at 191 . The idea of natural value caused considerable trouble for postbellum judges in the rate-setting cases. On value in the rate-setting cases, see FRIED, supra note 36, at 160-204; see also ATIYAH, supra note 40, at 296-298 (discussing natural value and the law of supply and demand in classical economics). 
but it can only finally be revealed by her social value-something measured most concretely by her suitors.

Sloper's linguistic style reflects and enforces the categorical abstraction of his reasoning. ${ }^{134}$ This is most evident in the explanations of his disapproval of Morris as a type, but is also evident in his frequent recourse to legal terminology. Throughout the novel we are told that Sloper perceives his judgments as not merely correct but "just."135 When Morris asks if Sloper thinks he will squander Catherine's money, Sloper states "I plead guilty." "136 After SIoper tells Catherine he will disinherit her if she marries Morris, Sloper warns Penniman: "Anything that you should do in the way of giving [Catherine] aid and comfort will be-permit the expression-distinctly treasonable. You know high treason is a capital offense: Take care how you incur the penalty." 137 And once Catherine has agreed to marry Morris, Sloper asks her to "give me definite notice" before she moves out of his house. ${ }^{138}$ Indeed, Sloper takes frequent recourse to legal Ianguage in order to convey finality and objectivity in situations that might otherwise prove difficult to explain or control. Postbellum judges, too, "often seemed to be trying to remove their decisions as far as possible from the specific facts and circumstances of the case. ... Thus insulated from the real world, the principles of law could appear absolute, undeviating in the face of appeals to sympathy or justice."139

Sloper's "idea of the beauty of reason," 140 his "scrupulously, formally polite" indifference, ${ }^{141}$ and his positive certainty of the justness of his "system"142 mirror the "compulsion by which an abstraction dictates, objectively, apolitically, in a non-discretionary fashion, a particular result" in classical legal orthodoxy. ${ }^{143}$ Sloper imagines himself as having no alternative than to act and judge as he does. The result, as Catherine observes, is that there is no possibility of "imparting any kind of [particularized] knowledge to her father; there was something superior even in his injustice, and absolute in his

134. As lan Bell has observed, it "codifies and freezes the world it inhabits by isolating the objects and the people of the world from any relational context, any communal enterprise." BELL, supra note 56 , at 76 .

135. See, e.g., id. at $46,51,74,146$.

136. JAMES, supra note 13 , at 76.

137. Id. at $117-118$.

138. Id. at $\mathrm{I} 50$.

139. WIECEK, supra note 24 , at 101. The often impassioned legal disagreements of the Civil War period opened the real possibility that legal discourse perceived as subjeetive would cease to provide the unitary account of law upon which legal and political institutions depended. See Norman W. Spaulding, The Discourse of Law in Time of War: Politics and Professionalism During the Civil War and Reconstruction, 46 WM. \& MARY L. REv. 2001 (2005).

140. JAMES, supra note 13, at 11 .

141. Id. at 12 .

142. Id. at 146.

143. Kennedy, supra note 84 , at 21 ; see also WIECEK, supra note 24 , at 101. 
mistakes."144

\section{B. Sentimentalism}

In stark contrast, Mrs. Penniman, Sloper's widowed sister-whom he invited "to make an asylum of his house while she looked about for furnished lodgings" but "settled herself with her brother and never went away",145 -is "rarely just." 146 The "flowery fields of her reason"147 are consistently inconsistent-Sloper insists that "the alphabet of common sense is something [she] will never learn" 148 -and she values "eloquence" over "veracity."149 Penniman is the novel's representative of postbellum sentimental culture, which held out "true feelings" and "concerns of the heart" as an antidote to the "hypocrisy" of "money and market relations." 150 Her world is entirely private, which is to say entirely domestic, and her greatest pleasure is in the experience of emotion, preferably sympathy with some romantic cause. ${ }^{151}$

Penniman is also a sentimentalist in the pejorative sense that hers is a taste for "easy vicarious indulgence in sentiment and romance" associated with the parasitic consumption of the suffering of others that marked late nineteenth century mass culture. ${ }^{152}$ Penniman's name itself invokes the explosion of the "penny press"—cheap, sensational, mass produced tabloids. ${ }^{153}$ Even as "class conflict posed fragmented realities that challenged the cohesion of any public sphere, the growing dominance of a mass culture-in the form of newspapers, magazines, advertising, and book publishing-created a national market which constructed for consumers a shared reality of both information and desire."154

144. JAMES, supra note 13 , at 95 .

145. Id. at 10-11.

146. Id. at 168 .

147. JAMES, supra note 13 , at 156 .

148. Id. at 117 .

149. Id. at 10,13 .

150. Nina Silber, The Romance of Reunion: Northerners and the South, i $865-$ I900 47 (1993).

151. In the sentimental frame of mind, suffering represented a genuine emotion which cut through economic and political pretenses and revealed true human feelings. . . It was felt that those who suffered, as well as those who were sympathetic to suffering, were emotional and caring people, not just vicious competitors in the public sphere.

SilbER, supra note 147 , at 51 .

152. Ian Watt, The Rise of the Novel: Studies in Defoe, Richardson and Fielding 290 (1957) (describing the rise of realism in the late eighteenth century). As Oscar Wilde famously put it, "a sentimentalist is simply one who desires to have the luxury of an emotion without paying for it." David Walton, Fashioning the Self from the Chasm: De Profundis and the Chronotope of Post-Prison Time, 22 Miscelánea: J. ENG. \& Am. STud. 1, 6 (2000).

153. See Trachtenberg, supra note 14, at 123 (describing the "penny press").

154. KaPLAN, supra note 54, at 12-13 (1988). Mass culture emerged out of technological advancements which, among other things, made the mass production of newspapers and especially photographs possible, contributed to the sense of dislocation experienced by new urban populations, and fed the expansion of market logic into literary and journalistic production. See 
In the postbellum urban landscape, "the apparently unique, the shocking, the 'new,' provided a way of making history seem immediate and personal just at a moment when its individuality and unpredictability had seemed to disappear." 155 Yet, "[t]he more people needed newspapers for a sense of the world, the less did newspapers seem able to satisfy that need by yesterday's means, and the greater the need for shock and sensation, for spectacle." 156 The result was the "new journalism," focused, in Joseph Pulitzer's words, on "what is original, distinctive, dramatic, romantic . . . odd, apt to be talked about."157 Not only did mass culture offer an apparent alternative to out-moded, "older forms of cultural authority," public discourse. ${ }^{159}$

James's portrayal of the culture of sentiment is entirely unsympathetic: Sloper refers to Penniman's world view as "mock romanticism"160 and it is mock, we quickly discover, beeause it is so thoroughly self-serving and superficial. ${ }^{161}$ More than anything eIse, Morris's courtship of Catherine strikes Penniman as an opportunity to make her own life more interesting. She plays an active part in the relationship not with Catherine's best interest at heart, but in order to appear to be "suffering in a romantic cause."162 This is more than selfishness. It amounts, finally, to a refusal to accept the actual emotional terms and stakes of daily life. Nothing is real for Penniman, a luxury she enjoys because she is supported by others and entirely irresponsible. She wants to "say the right thing," but she has no concept of doing the right thing. ${ }^{163}$

Catherine comes to think of Penniman's inconstancy as "innocent falsity." "164 But while it may be technically innocent, it has terrible repercussions. Penniman's bad and often contradictory advice is not merely capricious; her loyalties shift with her self-interest and in the end her only duty is to herself. For example, Penniman suggests that Morris and Catherine elope-she prefers the oxymoronic "private marriage" 165 - not because she

Trachtenberg, supra note 14, at 121-24.

155. See TraChtENBERG, supra note 14 , at 124-25.

156. Id. at 125 .

157. Id. at 124 .

158. KAPLAN, supra note 54, at 13.

159. See generally Richard Hofstadter, The Age of Reform: From Bryan to F.D.R. (1955) (describing sentimental language in progressive reform movements).

160. JAMES, supra note 13, at 51 .

161. See generally Jane Tompkins, Sensational Designs: The Cultural Work of AMERICAN FICTION 1790-I 860 (1985) (reinterpreting of the cultural work of sentimentalism in the late nineteenth century).

162. JAMES, supra note 13, at 96. James is careful to assure us that Penniman's interest in appearing in these romantic situations is entirely superficial or, in his word, "artificial"-her desire for Morris is aesthetic rather than specifie or sexual. Id. at 41. Even Penniman's own marriage is remembered primarily in terms of her husband's "flowers of speech." $I d$. at 10 .

163. Id. at 48 .

164. Id. at 152

165. Id. at 99. 
thinks it will cause Sloper to relent but because she imagines for herself a picturesque role in the proceedings. Once she learns that Morris does not love Catherine, Penniman feels no duty to warn or protect her niece. Rather, we are told that Penniman considers it "her duty, quite irrespective of Catherine" to help Morris get out of the engagement. ${ }^{166}$ Penniman's sense of the duties of other people is similarly unprincipled: she proposes that both Sloper and Catherine owe duties to the unscrupulous Morris, but not necessarily, as father and daughter, to each other-a proposition even Morris finds "ludicrous." 167 She clearly considers it Sloper's fraternal duty to support her, yet she openly flouts Sloper's arguable right to her allegiance (by encouraging the engagement he disapproves of, refusing to disclose to him Morris's "secrets," etc.) until he makes a direct threat to evict her. Aside from her own self-interest, Penniman has no conception of responsibility.

Liberty, for Penniman, is freedom from consequences. And the uses to which she puts that freedom are always transgressive. While Sloper and Catherine are away in Europe, she lets Morris treat the doctor's house like "a perfect castle of indolence," drinking Sloper's wine and spending hours smoking and musing in the doctor's private study. ${ }^{168}$ After Sloper's death, and finally secure in her enjoyment of the house in Washington Square under Catherine's countenance, Penniman feels even "more free to obey her impulses." 169 In her later years she takes the "liberty" of recasting the story of Morris's bad behavior in a light more favorable to him and her (which for her is its "true light"). ${ }^{170}$ And at the end of the novel, Penniman takes the "liberty" of inviting the middle-aged Morris into Catherine's house to rekindle his suit, violating Catherine's privacy and her trust. ${ }^{171}$

The self-interested alliance formed between Penniman and Morris, despite their fundamentally different intentions, reflects the postbellum convergence of picturesque culture, which began with the idealization of the home as a "retreat from the market," 172 and the emerging culture of consumption fed by the mass media and mass production. ${ }^{173}$ This unlikely alliance was at least partly

166. Id. at 168. Penniman's "romantic interest" in the "attractive and unfortunate" Morris derives from the fact that she finds herself more romantic and interesting in relation to him. Id. at 166. Having made the calculation that she herself will not be Sloper's heir, Penniman's romantic interest in Morris translates easily into the conviction that "it would not do for him to marry Catherine without [Sloper's money]." Id. at 170. Like Morris himself, she values his picturesque charm too highly to settle for less.

167. Id. at 101 .

168. Id. at 143 .

169. Id. at 208.

170. Id. at 211 .

171. Id. at 215 .

172. KAPLAN, supra note 54, at 145.

173. See The Culture of Consumption: Critical Essays in American History, $1880-$ I980 (Richard Wightman Fox \& T.J. Jackson Lears eds., 1983); T.J. JACKSON LEARs, FABLES OF Abundance: A Cultural History of Advertising in America (1995). In this way, 
facilitated by the subjectivity of value in both sentimental culture (where value is aestheticized) and the logic of the market (where value depends on demand). Penniman's standard of value is entirely aesthetic: her fondest hope is to be part of an "artistic tableau." 174 Indeed, we are told that "[e]ven the maternal instinct in Mrs. Penniman would have been romantic and factitious" and she favors Morris over Catherine because her niece "had never had that picturesque charm which (as it seemed to her) would have been a natural attribute of her own progeny." In contrast, Penniman would have "been very happy to have a handsome and tyrannical son" like Morris. ${ }^{175}$ The result of the mass market's commodification of sentimental values was the intrusion of commerce into the idealized Victorian home and the exposure of private relationships to the logic of the market. ${ }^{176}$

The superficiality of Penniman's values is reflected in the vacuousness of her language. She uffers Morris the dubious advice to "venture to appear as disinterested as you are"177 and describes his brief stint as a "commissions merchant" (which appears to be stock speculation) as "that dear little business: I think it's so brave of you!" 178 Catherine's preference to meet Morris in her father's "chintz-covered parlor" over a "sentimental tryst beside a fountain sheeted with dead leaves" strikes Penniman as almost perverse. ${ }^{179}$ Penniman also advances a number of specious legal conclusions in the novel, including her suggestion that "[i]t is not a crime when you are driven to it"180 and the idea that Morris might be able to sue Sloper for disinheriting his own daughter. ${ }^{181}$ Morris responds, "I will bring a lawsuit against you,"182 confirming SIoper's earlier warning that Penniman's trifling with Morris's real financial prospects might seem "a trick for which he may exact reparation [and] bring a suit against you." 183 Of course, neither man quite means it-Penniman doesn't have a penny, and what's more, no rational person could rely in good faith on her "fancies" and "delusions." 184

"sentimental power is reinvested in a market of consumer goods which serves as a retreat from the home and the workplace." KAPLAN, supra note 54, at 145. Here Kaplan is talking about Theodore Dreiser's 1900 novel, Sister Carrie, but the alliance of Penniman and Morris in Washington Square works this way as well.

174. JAMES, supra note 13 , at 96 .

175. Id. at 167 .

176. T.J. Jackson Lears, No Place of Grace: Antimodernism and the Transformation of American Culture, I880-I920 17.19 (1981) (describing the interplay between sentimental literature a 1 modern industrial capitalism).

177. Id. at 102 .

178. Id at 169 .

179. Id. at 61 .

180. Id. at 99 .

181. Id. at 170 .

182. Id.

183. Id. at 164 .

184. Id. at 117 . 
Morris comes to think of Penniman as a "humbug," Sloper calls her "ridiculous," and even Catherine finds her "meddlesome." 185 All eventually remark on her facility for "ruining an excellent cause."186 But despite Penniman's equivocal superficiality, sentimental discourse is far from marginal in the text. Indeed, James highlights the extent to which the tropes of sentimentalism have permeated cultural expectations. Sloper is uncharacteristically self-conscious in dissociating himself from the appearance of sentimentalism, insisting to Morris that he is "not a father in an oldfashioned novel," 187 and by the end of the novel we suspect that his fear of being made to "appear ridiculous" 188 has motivated his disinheritance of Catherine as much as any principle. Morris's mercenary suit of Catherine is thoroughly unsentimental, but he woos her, and later manages her, in the language of sentiment. ${ }^{189}$ And everyone expects Catherine to "[make] a scene," and otherwise act the sentimental part of the "lovelorn maiden," even though therc's nothing "scenic" about her. ${ }^{190}$ Penniman's eternal youth-at the end of the novel, past the age of sixty, she "was quite a girlish figure" "191 — signals James's impression that neither the cynical cooptation of, nor local resistance to, sentimental culture diminishes its discursive ubiquity or social resonance.

For most of Washington Square, SIoper the empiricist and Penniman the sentimentalist are nearly incapable of communication, so great is the gulf between their understandings. At the crucial moment, however, Sloper suggests that "[i]n spite of differences ... we can, at a pinch, understand each other" and his threat to evict her for "treason" 192 successfully realigns Penniman's interests with the command of the "great autocrat."193 The implication here that the impersonal authority of formalism is required to contain sentimental disorder provides some insight into the appeal of legal science in the postbellum period. As we shall see, Morris's self-interested but much more pragmatic vocabulary proves considerably more difficult for Sloper to manage than Penniman's precisely because its intellectual underpinnings in classical liberalism are so much closer to those of legal ortbodoxy. ${ }^{194}$

185. Id. at $97,80,105$.

186. Id. at 80 .

187. Id. at 78 .

188. Id. at 57 .

189. See, e.g., JAMES, supra note 13, at 26 ("It was the way a young man might talk in a novel, or, better still, in a play."), 60 ("He has taunted me with my poverty."), 176 ("[Y]ou must take me as 1 am.").

190. Id. at 80 .

191. Id. at 202-03. We are told that "[h]er ringlets, her buckles and bangles glistened more brightly with each succeeding year, and she remained quite the same officious and imaginative Mrs. Penniman." Id.

192. Id. at 117.

193. Id.

194. See WIECEK, supra note 24 , at $82-83,92$ (describing the nexus of classical economics and legal science); see also АтIYAH, supra note 40, at 292 (describing the close connections 


\section{Economic Opportunism and Free Market Individualism}

Classical economics, in much the same spirit as legal science, distilled general laws from the observation of complex social and economic activity. The axioms it generated-the law of supply and demand, the "naturalness" of prices, the maximal efficiency of free markets and freedom of contractsuggested a new conception of society in which individual actors pursuing their own self-interest would produce optimal results for society generally. ${ }^{195}$ By the late nineteenth century, "faith in autonomous selfhood required a denial of inner conflict and an insensitivity to actual social conditions." 196 But classical liberalism's longstanding commitment to government non-intervention suggested a justification for this indifference: the doctrine of laissez-faire. In the logic of laissez-faire, inequality was a necessary cost of liberty and any redistribution of wealth would ultimately worsen conditions for all. ${ }^{197}$ Thus the pursuit of individual interest-at any lawful expense to others-was not just acceptable, but valorized. ${ }^{198}$ Whether or not most Americans subscribed to classical liberal, let alone laissez-faire, economics, the rhetoric of laissez-faire emerged as the dominant economic vocabulary in postbellum America. ${ }^{199}$

Catherine understands from their first meeting that Morris's "positive, offhand" manner is a kind of performance. ${ }^{200}$ But unlike the "artificial" Penniman, ${ }^{201}$ Morris seems to Catherine "not like an actor; he seemed so sincere, so natural."202 Morris's "naturalness" is a recurring motif in their interactions, and for both Morris and Catherine, "naturalness" is the opposite of

between classical economics and utilitarianism); AustıN, supra note 88, at 79 (discussing the "utility" of self-interest).

195. See supra note 39; see also АтІчан, supra note 40, at 295-321 (describing the principles and assumptions of classical economics).

196. LEARS, supra note 176, at 18. In its nineteenth century American incarnation, the "autonomous self was a Promethean figure, conquering fate through sheer force of will"-the "self-made man." Id. at 18. Lears observes that "social historians have conclusively demonstrated that gross inequalities of opportunity existed in the Umited States during the Jacksonian era; by the 1880 s the growth of organized corporate capitalism had made genuine economic independence a near impossibility." Id. at 18.

197. William Graham Sumner, What the Social Classes Owe to Each Other 16, 124 (Ayer Co. ed. 1987) (1883).

198. Sumner offered this account:

A society based on contract is a society of free and independent men, who form ties without favor or obligation, and cooperate without cringing or intrigue. A society based on contract, therefore, gives the utmost room and chance for individual development, and for all the self-reliance and dignity of a free man. . . . [T] he only social improvements which are now conceivable lie in the direction of more complete realization of a society of free men united by contract....

SUMNER, supra note 197 , at 26.

199. WIECEK, supra note 24 , at 83 ; FRIED, supra note 36 , at 31 .

200. JAMES, supra note 13 , at 26.

201. Id. at 41 .

202. Id. at 26 . 
exaggeration. ${ }^{203}$ But that opposition means something very different to each of them. For Catherine, naturalness signals authenticity and, by implication, sincerity. ${ }^{204}$ Because Morris seems so natural, she believes that his motives are "pure.,"205 For Morris, naturalness means something more like expediency. For example, when Sloper points out the relative alacrity with which Catherine and Morris have become engaged, Morris observes that the decision to marry "was very natural, from the moment we were sure of ourselves-and of each other." 206 Naturalness is also, for Morris, linked to empiricism: "to see for yourself - that was the great thing; he always tried to see for himself."207 Morris's naturalness is individualistic and self-interested; where it signifies virtue for Catherine, for Morris it justifies self-indulgence. Morris's naturalness, in other words, is guided by the "natural law" of classical economics, through which each individual's pursuit of his desires orders society in a market governed by supply and demand. ${ }^{208}$ ln the world of classical economics, as Sloper himself observes, "it is right to get all you can." 209

Morris's naturalness is thus associated in the text with a certain kind of liberty, and a certain notion of value. In contrast with Catherine's fundamental goodness and her conception of value as intrinsic, Morris's most superficial qualities are his defining characteristics. Even the doctor has to admit that Morris is a "beautiful structure," 110 and one of the central questions of the text is whether this beauty constitutes value. Before confirming Sloper's suspicions about her brother's selfishness, Morris's sister offers up Morris's "talents"which we understand to include his appearance, his charm, his worldly experience, his singing voice, and his sparkling conversation-as a kind of

203. Id. at 39.

204. Lionel Trilling describes "sincerity" in the Victorian imagination as "the avoidance of being false to any man through being true to one's own self." LIONEL TrILling, SINCERITY AND Authenticity 5 (1972). Catherine's conflation of apparent sincerity and authenticity, though, is too simple.

Society requires of us that we present ourselves as being sincere, and the most efficacious way of satisfymg this demand is to see to it that we really are sincere, that we actually are what we want out community to know we are. In short, we play the role of being ourselves, we sincerely aet the part of the sincere person, with the result that a judgment inay be passed upon our sincerity that it is not authentic.

Id. at 10-11. Authenticity represents "a more strenuous moral experience than 'sincerity' does, a more exigent conception of the self and of what being true to it consists in, a wider referenee to the universe and man's place $m$ it, and a less acceptant and genial view of the social eireunustances of life." Id. at 11 .

205. JAMES, supra note 13 , at 95 .

206. Id. at 74 .

207. Id. at 39.

208. ATIYAH, supra note 40, at 295 (discussing "natural law" in classical economics).

209. JAMES, supra note 13 , at 86 .

210. Id. at 49. 
defense to Sloper's accusations. ${ }^{211}$ As for Morris himself, "with his fine parts he rated himself high, and he had a perfectly definite appreciation of his value," 212 a value based on the appeal of his person and not of his character. But ultimately, Morris's conception of value is a market-based conception of value: you are worth as much as someone will pay to have you. ${ }^{213}$

On one level Morris is a typical literary villain-“"a person who seeks to rise above the station to which he was born." 214 A villain "is not what he is ... because by his intention he denies and violates his social identity and because he can achieve his unnatural purpose only by covert acts, by guile." 215 But James's representation of Morris in Washington Square registers the (then new) possibility that the logic of the market erases authenticity or natural purpose in social identity. If the only obligations between persons pursuing their own self interest are those they freely choose to enter, the station into which one is born is as irrelevant as the idea of authenticity itself. Morris can be entirely sincere in his attempt to get as much as he can. Rather, it is Catherine's Victorian expectations that are out of line with the realities of lived experience.

The particular version of liberty that arises from the logic of the market manifests in Morris as a disdain for work. Having entered the market as a beautiful object, condescending to work would admit the possibility that Morris should earn a living rather than be paid for his personal qualities. ${ }^{216}$ Sloper perceives correctly that the "position" best suited to Morris's talents is as the husband "of a weak-minded woman with a large fortune." 217 The "sign of the type in question" Sloper further observes, "is the determination-sometimes terrible in its quiet intensity-to accept nothing of life but its pleasures . . . . Young men of this class never to do anything for themselves that they can get

211. Id. at 90 .

212. Id. at 134 .

213. The notion of "natural" or inherent value corresponded to a "physicalist" conception of property as tangible objects that informed classical liberalism. FRIED, supra note 36, at 191. In contrast with the traditional conception of property as "things that are owned by persons," by the postbellum period the development of the industrial market economy had gencrated new forms of property that were abstract and immaterial. Thomas C. Grey, Disintegration of Property, in Property: Nomos XXII 69, 76 (J. Roland Pennock \& John W. Chapman eds., 1980). Over the course of the postbellum period, the abstraetion of property was reflected in the legal recognition of "property" as diverse as personal charaeteristics, reputation, and the expectation of future earnings. See Horwitz, supra note 27, at 145-146. In his dissent in the Slaughterhouse Cases, Justice Noah Swayne famously wrote, "Property is everything which has exchangeable value." 83 U.S. (16 Wall.) 36, 127 (1872).

214. TRILLING, supra note 204 , at 16 .

215. Id.

216. Morris tells Penniman "with an air of intellectual independence" that he eonsiders being a doetor-getting paid to render service to others-" "an extremely loathsome profession." JAMES, supra note 13, at 102. When Morris does eventually find a job (to convinee Sloper he is financially viable) he goes into "partnership with a commission merchant" because, as Penniman tells Catherine on his behalf, he "could never be a subordinate." Id. at 153 .

217. Id. at 55 . 
other people to do for them." 218 In this way, Morris would seem to be the doctor's opposite. But James complicates their opposition in two interrelated ways. First, Morris may be selfish (which is undesirable) but he is also free (which, compared with Catherine's fate, is clearly desirable). Second, in the contest between Sloper and Morris, we discover unexpected similarities. ${ }^{219}$ Put simply, Morris may be dissimulating-playing a role-but Sloper is too. And for each man, being "clever"-which turns out to mean making calculated judgments based on abstract principles derived from observed experienee- is requisite. $^{220}$

The social role Sloper plays, as a physician and as a father, is that of the impartial and scientific judge. The role that Morris plays is much more like that of an investor. Having won Catherine's heart but not Sloper's approval, Morris must choose between settling for Catherine and her $\$ 10,000$ a year with only a slight hope of seeing the doctor's money, or abandoning Catherine to pursue an income more commensurate with his self-estimated value. Weighing these options, he is aware that "Providence was more especially on the side of clever people, and clever people were known by an indisposition to risk their bones." ${ }^{221}$ But as an investor, Morris must not only take risks, but also balance risks and rewards with imperfect information. Indeed, Morris conceives of his situation as essentially a mathematical problem in which "Doctor Sloper's opposition was the unknown quantity ... he had to work out." "222 Morris concedes that the "natural way to work [the problem] out was by marrying Catherine; but in mathematics there are many shortcuts, and Morris was not without a hope that he should yet discover one." 223 In other words, Morris's math is the math not of immutable abstractions (geometry) but of economic realities-sensitive, in the individual case, to social factors. The shortcut Morris gambles on-sending Catherine to Europe with her father with the instruction to be clever-fails miserably. When she returns and reports her failure, Morris regards the fact that Sloper "will never give us a penny . . . as

218. Id. at 88 .

219. Critics have remarked on this similarity widely. See, e.g., William Kenney, Doctor Sloper's Double in Washington Square, 36 U. REv. 301, 301-306 (Junc 1970).

220. Sloper's cleverness is first described in terms of his reputation: "his learning and his skill were very evenly balanced; he was what you might call a scholarly doctor, and yet there was nothing abstract in his remedies - he always ordered you to take something." JAMES, supra note 13, at 5. Aftcr their first meeting, Catherine observes to Morris's cousin, who has confirmed Morris's general brilliance, "1 suppose you can't be too clever." The cousin's response is telling: "1 know some people that call my cousin too clever." Id. at 34.

221. Id. at 133 .

222. Id. at 134 ("[W]ith his fine parts he rated himself high, and he had a perfectly definitc appreeiation of his value, which seemed to him inadequately represented by the sum 1 have mentioned. At the same timc he reminded himself that this sum was considerable, that everything is relative, and that if modest income is less desirable than a large onc, the complete absence of revenue is nowhere accounted an advantage.").

223. Id. at 134 . 
mathematically proved., 224

Morris thinks nothing of defying Sloper's paternal authority in the pursuit of his own interests, takes advantage of Penniman's infatuation openly and without scruple, and pitilessly draws on the "fund of affection" for him in Catherine's heart. $^{225}$ He doesn't even feel an obligation to break off his engagement with Catherine in person, trying first to get Penniman to do it for him, then to induce Catherine to quarrel with him (an impossibility, in light of her "treasures of concession") ${ }^{226}$ and finally breaking the news by letter-a hollow, "explanatory document" casting them as "innocent but philosophic victims of a great social law." 227 He possesses no sense of duty by any standard of obligation. Like his co-conspirator Penniman, he is free from traditional moral scruples, completely irresponsible.

Another way of describing Morris's interpersonal interactions is to say that they conform to the classical legal theory of contract. ${ }^{228}$ Classical contract theory envisions one-time exchanges between strangers in which parties strike bargains that are mutually beneficial. ${ }^{229}$ Mutual benefit is not, however, a condition of the enforceability of the contract, as contracts are narrowly construed. ${ }^{230}$ Indeed, the relative fairness of the contract does not faetor into its legal enforceability. Thcre is no requirement "that one party does not take advantage of another, or impose unreasonable terms by virtue of superior bargaining position." 231 Rather, classical contract theory begins with "the proposition that, ideally, no one should be liable to anyone for anything." 232 In this scheme, the promise behind a technically incomplete contract has no contractual force: "if $\mathrm{A}$, without the protcction of a binding contract, improvidently relies, to his detriment, on B's promises and assurances, that might be unfortunate for A but it is no fit matter for legal concern." ${ }^{233}$ Hence Morris's indifference to Catherine's plight. Classical contract theory is of a piece with the broader trend of lcgal science in its "deliberate renunciation of

224. Id. at 170 .

225. Id. at 78 .

226. Id. at 176 .

227. Id. at 193-94.

228. James was acutely perceptive of the ascendancy of the logic of contract in the American imagination in the postbellum period. And in James's world of interpcrsonal exchanges, profit results from imbalances, from domination and vulnerability. For James, even in transactions in which both parties benefit, a personal loss is involved-everything has a cost. See Brook Thomas, American Literary Realism and the Falled Promise of Contract 53-87 (1997).

229. Langdell's theory of contract is exemplary of the application of legal science to the common law to distill formal, abstract guiding principles. Grey, supra note 28 , at 4 . In classical legal thought, "all persons were presumed equals in bargaining relationships." WIECEK, supra note 24 , at 10 .

230. ATIYAH, supra note 40 , at $402-03$.

231. Id. at 404 .

232. Grant Gilmore, The Death of Contract 14 (1995).

233. Id. at 15 . 
the particular" and determination not "to restrict untrammeled individual autonomy or the completely free market in the name of social policy."234 In his unapologetic pursuit of his own self-interest Morris embodies the logic of classical contract in social action. ${ }^{235}$

But Catherine is not alone in suffering the consequences of Morris's liberty. Morris suffers as well. Without a clearly defined social role to play, Morris's cleverness is stretched to its limits. Despite his "constant habit of seeking to be agreeable," 236 he badly misjudges the correct tone to take with Sloper when pleading his suit. Morris first offers the sentimental promise of "the most tender affection and a lifelong devotion" on "the word of a gentleman" but Sloper has already concluded that Morris is no gentleman and suggests to the young man that a "lifelong devotion is measured after the fact." ${ }^{237}$ Morris next attempts a distinctly Victorian narrative of reformation: "I have been wild; I have been foolish. . . I have nevcr concealed that. But I have sown my wild oats . . . I assure you I have reformed. . . . And I made no debts; when it was gone, I stopped. I don't owe a penny in the world." ${ }^{238}$ When this approach also fails, Morris protests, "you are very unjust," to which Sloper responds, "it is your privilege to think so." 239 Morris is incapable of judging the correct way to talk to Sloper because Morris cannot penetrate Sloper's abstractions. But his several attempts demonstrate Morris's polyglot abilityhe shifts between cultural vocabularies as he shifts betwecn sociaI interactions. The logic of the market requires such conceptual flexibility in the pursuit of self-interest, though it is also clearly an obstacle to personal integrity. When we get our first glimpses of Morris's interiority, more than half way through the novel, his self-perception is speculative and commodified. ${ }^{240}$

Despite his high estimation of his own value on the social market, Morris does not get what he thinks he deserves. At the end of the noveI we Iearn that he "has been all over the world, and tried to establish himself everywhere [but]

234. Lawrence M. Friedman, Contract Law in America 20, 21 (1965).

235. Legal historians have suggested that classical legal thought was little more than an apology for laissez-faire political and economic policies. See, e.g., ATIYAH, supra note 40, at 402; HoRwitz, supra note 27 , at 36 . But A. W. B. Simpson and others have argued that this conclusion is overly reductive. See James Gordley, Contract, Property, and the Will-The Civil Law and Common Law Tradition, in The State and Freedom of Contract 66 (Harry N. Scheiber ed. 1998); David Lieberman, Contract Before "Freedom of Contract," in The STATE AND Freedom of Contract 89 (Harry N. Scheiber ed. 1998); A.W.B. Simpson, The Horwitz Thesis and the History of Contracts, 46 U. CHI. L. REv. 533 (1979). Duncan Kennedy usefully explains that legal consciousness "is a set of concepts and intellectual operations that evolves according to a pattern of its own, and exercises an influence on results distinguishable from those of political power and economic interest." Kennedy, supra note 84 , at 4.

236. JAMES, supra note 13 , at 97.

237. Id. at 75 .

238. Id at 76-77.

239. Id at 77 .

240. Id. at 133. 
[e]verything failed." ${ }^{241}$ Here James anticipates what would quickly become clear about the formalism of classical contract law specifically and the assumptions of classical economics generally: the complexities of social and economic life belie neat ideal conceptions. In reality, "individual success" is often tied to the success of a "mutual venture," 242 the free market fails to correct unequal bargaining power, and the state is often already more or less involved. ${ }^{243}$ Morris's ambitions are thwarted, James implies, by the combination of his atomistic self-interest (or the refusal to cooperate) and the misconception that the market will determine his value without reference to social codes of behavior (something like state intervention).

In the postbellum period, the lingering cultural authority of Victorian values posed a significant obstacle to the coherence of both legal science and classical economics (which took the form, increasingly, of laissez-faire ideology). Victorian reformers "espoused middle-class, moderate, and moralistic reforms to the structure of government," helping to create "the regulatory apparatus of the modern administrative state." 244 Populists, who did not share Victorians' conservatism, nevertheless borrowed their moralistic rhetoric, particularly as they lamented the maldistribution of wealth between workers and capitalists. ${ }^{245}$ James clearly recognized the peculiar fortitude of Victorian culture in the face of social and economic developments that rendered most of its foundational assumptions obsolete. Both Sloper and Morris underestimate Catherine-the novel's representative Victorian--and at the end of the novel she remains, despite their betrayals, very much herself.

\section{Victorian Values}

Catherine is "excellently, imperturbably good; affectionate, docile, obedient, and much addicted to speaking the truth."246 Her behavior and expectations are distinctly Victorian, reflecting a belief in "the order of the universe, in the ineluctable duty it silently lays upon us, [and] the validation of such personal coherence and purposiveness as we can claim for ourselves."247

241. Id. at 211 .

242. Jay M. Feinman, The Significance of Contract Theory, 58 U. CiN. L. REv. 1283, 1287 (1990). See Jay M. Feinman, Relational Contract Theory in Context, 94 Nw. U. L. Rev. 737 (2000); lan R. Macneil, Values in Contract, 78 Nw. U. L. REv. 340 (1983).

243. FrIED, supra note 36 , at 82.

244. WieceK supra note 24, at 77. See generally, John G. Sproat, The Best Men: LiBeral ReFormers in THE GILDED AGE (1968).

245. WIECEK supra note 24, at 77. See generally HoFsTADTER, supra note 159

246. JAMES, supra note 13, at 13. Literary critics have tended to interpret Catherine Sloper's passivity as a sign of her commodification, her status as an expensive object. lan F. A Bell, "This Exchange of Epigrams": Commodity and Style in Washington Square, 19 J. AM. STUD. 48, 60 (1985).

247. TRILLING, supra note 204, at 118. Daniel Walker Howe understands Victorianism in 
Above all else, Victorian culture involved the vindication of Victorian values, which included hard work, the postponement of gratification, selfimprovement, and self-control. ${ }^{248}$ The pursuit of these values was both social and personal and the Victorian vocabulary, "laden with words like 'duty' and "virtue," reflected the seriousness with which these values were taken. The Victorian ideal of character-"an intangible strength of purpose, combining self-reliance, self-discipline, and responsibility"-insured that "the emotions always remained complementary and subordinate to rational order.",249

Catherine is neither beautiful nor brilliant (facts which her father frequently takes occasion to observe), but she is preeminently good. And while she is also not clever, she is patient, undemanding, self-disciplined, and finally impressively, authentically sincere. In response to the major crises of her relationship with Morris, Catherine's primary concern is "to be just as usual" ${ }^{, 250}$ - to be good, to behave appropriately, to be hcrself. Indeed, Catherine's identity is based in the Victorian ideal of "emotional harmony" in domestic life - the "preservation of moral order" within the family provided the stronghold of Victorian values. ${ }^{251}$ Thus when the doctor tells her that he does not approve of her engagement to Morris, she feels it would be inappropriate to manipulate her father by making her emotional troublc public. ${ }^{252}$ Instead, she absorbs the crushing blow, at least outwardly, "as a matter of course." 253 Her apparent lack of emotion strikes Sloper as "unnaturally passive," but he misreads her self-control, and misses the extent to which "trying to be a good daughter" has become for her "a state of expectant suspense about her own actions." 254

When Morris pushes her to choose, as it were, between himself and her father, Catherine rejects the idea of a choice entirely. Her Victorian sensibilities preclude a violent break with her father as surely as they preclude acceptance of the idea that order and harmony are not inevitably restored through virtue

the American context as largely the product of the "new urban middle class," or bourgeoisie, which had emerged from the industrial revolution by the 1830s. Howe, supra note 39, at 9-10. Howe asserts that "American Victorianism was not the exclusive attribute of any social group or groups within the United States; it was a set of cultural motifs." Id. at 12-13.

248. Howe suggests that the "Victorian preoccupation with order probably reflected a need for psychological stability amidst rapid changes occurring during the nineteenth century. One must be cautious about thinking of this impulse toward order as simply 'conservative,' however . . . Even Victorian prudery was an innovation." Id. at 19.

249. Id. at 21, 25; see also TRILling, supra note 204, at 110-11 (on the "chief qualitics of probity and candour" and "sincerity, by which [Victorians] meant their single-minded relation to things, to each other, and to themselves").

250. JAMES, supra note 13 , at 120.

251. LEARS, supra note 176 , at 15.

252. JAMES, supra note 13 , at 114.

253. Id. at 80 .

254. Id. at $92-93$. 
and duty. ${ }^{255}$ "The idea of a struggle with her father, of setting up her will against his own, was heavy on her soul, and it kept her quiet, as a great physical weight keeps us motionless." 256 Nevertheless, it "never entered into her mind to throw her lover off," which would at this point also constitute an unacceptable rupture. ${ }^{257}$ Rather, "she tried to assure herself that there would be a peaceful way out of their difficulty:"

The assurance was vague, for it contained no element of positive conviction that her father would change his mind. She only had an idea that if she should be very good, the situation would in some mysterious manner improve. To be good she must be patient, outwardly submissive, abstain from judging her father too harshly, and from committing any act of open defiance. . . . Of course [her father] could not know what she knew-how the purest love and truth were seated in [Morris's] eyes . . . . But she could at least be good, and if she were only good enough, heaven would invent some way of reconciling all things - the dignity of her father's errors and the sweetness of her own confidence, the strict performance of their filial duties, and the enjoyment of Morris Townsend's affection. ${ }^{258}$

Her faith in the triumphal power of Victorian values here is absolute. And her response to Sloper's subsequent threat to disinherit her if she marries Morris is also thoroughly Victorian. She does not care about the money, rather "the terrible word disinheritance, with all its impressive moral reprobation" leaves her "overwhelmed by a feeling of loneliness and danger." 259 To be disinherited is to have failed of virtue, duty, and goodness. Even Morris recognizes that it represents for Catherine "a kind of curse." 260

Catherine recognizes that Sloper's disapproval of her engagement renders her own feelings for Morris, which are otherwise pure and innocent, "bad."261 But she believes Sloper's abstract, categorical reasons for rejecting Morris must be in error because she is so completely convinced of Morris's love, of the sincerity of the man, not the type. ${ }^{262}$ The (for her) inexplicable deviation of her own and her father's assessment of Morris induces her to "try to appear good, even if her heart were perverted; and from time to time she had a fancy that she might accomplish something by ingenious concessions to form." ${ }^{263}$ But once

255. Howe, supra note 39, at 18, 20.

256. JAMES, supra note 13 , at 94.

257. Id.

258. JAMES, supra note 13 , at $94-95$.

259. Id. at 127 .

260. Id.

261. Id. at 120 .

262. "In the deterministic world of the orthodox liberals no individual suffered economic hardship except as a result of his own shortcomings." SPROAT, supra note 244, at 206. In contrast Catherine sees no reason to hold Morris's poverty against him, preferring to judge him by his personal behavior.

263. JAMES, supra note 13 , at 120. 
she finally agrees to go through with the marriage, even ingenious concessions cannot keep her within the forms that define her moral code. So intense is her "sentiment of duty" 264 that she feels that she has broken "a sacred law" by agreeing to marry Morris against her father's wishes. ${ }^{265}$ And her situation is made considerably more difficult by the fact that Morris quickly backs away from his offer of immediate marriage and encourages Catherine to travel to Europe with her father.

When she confesses her sense of having forfeited "his .kindness and protection," 266 Sloper masks neither his indifference nor the contempt of his rebuke that "the idea is in very bad taste." 267 Not only is this response unnatural for a father by Victorian standards, ${ }^{268}$ his failure to appreciate and respond appropriately to her candor and sincerity eases the crushing sense of duty that has prevented her happiness. ${ }^{269}$ She still travels to Europe with Sloper at Morris's behest and "out of respect to her father." 270 But when, at a "desolate and lonely" pass in the Alps, Sloper confesses his anger "that she has not yielded an inch" 271 and assures her that he "can be very hard,"272 Catherine recognizes that he has no regard for the integrity of her feelings. ${ }^{273}$ "I have been as good as I could," she tells Penniman, "but he doesn't care. Now I don't care either." 274 Catherine's sense of duty has not changed, but she now feels that Sloper has forfeited his right to it.

If Sloper had been wrong about Morris, and Catherine had been right, Sloper's disapproval - and even disinheritance - would not have stung her after her discovery of her father's indifference. ${ }^{275}$ But Catherine's subsequent renunciation of any claim on her father's money finally convinces Morris to abandon her. Heartbroken ("the two great facts of her career were that Morris Townsend had trifled with her affection, and that her father had broken its

264. Id. at 78 .

265. Id. at 135 .

266. Id. at 137 .

267. Id. at 138 .

268. "One of the most prominent relationships in [Victorian] families was the mutual reliance of fathers and daughters. As daughters grew up, fathers made them companions. Young women, in turn, found it hard to hreak free of the same affectional ties." ANNE C. RosE, Victorian AMERICA AND THE Civil War 164 (1992).

269. JAMES, supra note 13 , at 140 ("She felt in every way at present more free and more resolute.").

270. Id. at 140. Catherine does not however share Penniman and Morris's notion that "if she should be a little clever about it, and touch the right chord, perhaps [Sloper] would fold her in his arms, and tell her that he forgave her." Id. at 142.

271. Id. at 147,148 .

272. Id. at 147.

273. Catherine also recognizes that "men so clever as he might say anything and mean anything." Id. at 149.

274. Id. at 156.

275. She has made the discovery, in the Alps, that her father "is not very fond" of her. Id. at 160. 
spring”), Catherine is thrown back on her Victorian values to make the rest of her days in her father's house practicable: "There was something dead in her life, and her duty was to try to fill the void." 276 She becomes "an admirable old maid" who "formed habits, regulated her days upon a system on her own, interested herself in charitable institutions, asylums, hospitals, and aid societies; and went generally, with an even and noiseless step, about the rigid business of her life."277 And while she is "greatly liked," "her opinions, on all moral and social matters, were extremely conservative; and before she was forty she was regarded as an old-fashioned person, and an authority on customs that had passed away." 278 The discipline of Catherine's Victorianism prevents her from enjoying her liberty even after her father's death and the novel closes with her seated in her parlor, with her fancy work, "for life, as it were.",279.

The Victorian New York that Catherine represents struck the young Edith Wharton (James's friend and literary contemporary) as "an empty vessel into which no new wine would ever again be poured," though in later years Wharton appreciated the "unsuspected value" of its "concerted living up to long-established standards of honour and conduct, of education and manners." ${ }^{280}$ While there is clearly no future in it, James too finds unsuspected value in Catherine's probity, as compared to Penniman's frivolousness, Morris's calculation, and Sloper's irony. Catherine's lack of cleverness annoys both Sloper (who would like his daughter to be a credit to his own cleverness, or at least, short of that, provide him a bit more amusement) and Morris (who would like a bit more help from her in the manipulation of Sloper), and at one point Catherine even describes herself as "stupid." 281 But by the end of the novel she has managed to surprise not just Sloper and Morris but also the reader. James does not think she is stupid. Rather, cleverness and brilliance are judged by those around her in terms of verbal prowess ${ }^{282}$ and Catherine is simply "inarticulate." 283

276. Id. at 202.

277. Id. at 201-202. "Most Victorians expected girls to realize the call to take responsibility for others" through participation in "philanthropic and benevolent activities." LOUISE STEVENSON, The Victorian Homefront: American Thought and Culture, 1860-1880 7 (1991).

278. JAMES, supra note 13 , at 202.

279. Id. at 219. On the role of the parlor in Victorian culture, see STEVENSON, supra note 277 , at $1-30$.

280. EDITH Wharton, A BaCKWARd glance 5 (1933).

281. JAMES, supra note 13 , at 60 .

282. Weisberg and Binder observe that under modern conditions, every social interaction has a competitive or strategic dimension. Every interaction takes place within a general contest over cultural authority. ... [T] he display of literacy, aesthetic refinement, and rhetorical skill are all means of staking a claim to 'distinction,' social status, and symbolic capital. The 'literary' use of language therefore has a practical, power-enhancing dimension.

WEISBERG \& BINDER, supra note 7 , at 477.

283. Id. at 17. Her choice of dress is an attempt to "articulate herself." Id. Though if Mrs. 
We know much of what we will need to know about Catherine's relationship to language from the revelation at the outset of the novel that Sloper "almost never addressed his daughter save in the ironical form." 284 Our first direct experience of Catherine's "diffidence of speech" 285 follows the party where Catherine first meets Morris. On the carriage ride home, Sloper and Penniman banter lightly about Morris's interest in the girl while she herself sits largely silent, only occasionally interjecting faint, ineffectual exclamations ("oh, Aunt Penniman!," "oh, father!") until finally the conversation ends in her refusal to name Morris at all. ${ }^{286}$ This refusal is significant because it represents what we are told is a new phase in Catherine's verbal life: until meeting Morris, Catherine has never "made an indirect answer." 287 In this way, the beginning of her courtship also begins "a period of dissimulation" ${ }^{288}$ for Catherine-but it is not dissimulation toward immoral ends. Catherine cannot be accused of any moral violation in the text. Rather, in Morris she has found something she wishes to protect from the clever, ironic speech around her: her first lie comes in response to her cousin's teasing that Catherine's pleasure in Morris's attention has been too keen, her second lie deflects Sloper's teasing implication that Morris was attracted to Catherine because her opulent dress suggests her fortune, the third resists Penniman's self-importance in relating Morris's interest in Catherine. In other words, not saying provides a way of protecting "something precious" from the degradation and cooptation of public discussion. ${ }^{289}$

This is, of course, eminently Victorian-the positive side of the "scrupulous probity" which prompted Victorians' refusal to name so many things for fear of losing control of them in the naming. ${ }^{290}$ In the novel, Catherine's inarticulateness is clearly connected to an unwillingness to give expression to ideas she believes to be either inappropriate or too personal-it is a necessary tool of her self-discipline. Tragically, and James's point is that this is tragic, the rigorous and conceptually narrow Victorian vocabulary that constrains Catherine's expression equips her with neither the assertiveness to challenge Sloper's abstract judgments nor the cynicism to mistrust Morris, even as the engagcment drags on and she begins to feel "a want of perfume in the

\footnotetext{
Almond is correct that her rich dress has discouraged more appropriate suitors, that selfexpression has in fact misrepresented her. Id. at 42.

284. JAMES, supra note 13, at 28. ("Whenever he addressed her he gave her pleasure; but she had to eut her pleasure out of the pieces, as it were. There were portions left over, light remnants and snippets of irony, which she never knew what to do with, which seemed too delicate for her own use.").

285. Id. at 18 .

286. Id. at 28-30.

287. Id. at 28 .

288. Id.

289. Id. at 26.

290. WHARTON, supra note 280 , at 21 .
} 
air" between them. ${ }^{291}$ For Catherine, Morris's promises are "naturally" binding, and though on a sentimental account, "[1] ove demands certain things as a right," Catherine has "no sense of her rights" with regard to Morris, "only a consciousness of immense and unexpected favors." 292 In other words, Catherine is made vulnerable by the very conceptual narrowness she believes will protect her. Penniman is the only person Catherine is finally able to "judge" correctly ("jumping all processes" and "without appeal") when she realizes her aunt has helped Morris to decide to break her heart. ${ }^{293}$

Catherine's personal integrity comes at the cost of an ability to communicate effectively - to translate her assumptions and expectations into the public language of legal science or laissez-faire, to use language as power. She understands this well enough to turn down the subsequent marriage proposal of a "clever young lawyer" who was "scriously in love with her."294 Her identity is only possible in the private, domestic confines of the house on Washington Square, and even here, as we have seen, she is not safe from the vagaries of the competitive, impersonal world outside its doors.

III

\section{IRONY IN WASHINGTON SQUARE}

Sloper wants to leave his daughter at liberty to make her own choice about Morris, but he is also convinced that there is only one correct choice to be made. In this way, Sloper exemplifies the difficulty for classical liberalism generally and legal classicism more specifically at the end of the nineteenth century. For all his apparent formalism, Sloper, like John Stuart Mill and other nineteenth century liberals, is fundamentally committed to a specific ideal: "an interactive balance of moral freedom and individual spontaneity" in which:

freedom means the capacity of self-government-the capacity of ordering one's actions by what one is oneself able to recognize as good reasons. . . . So it assumes that there is something to be cultivated, something to be got right; it involves the idea of right, appropriate feeling - the overcoming of immaturity, stuntedness, repression, as also of distorting limitations, delusions, enslaving emotional needs, and then beyond that, the development of insight. ${ }^{295}$

This is what Sloper expects of his daughter when he charges her to make her own decision; his experiment amounts to a test of the power of liberal ideology.

In its correlation of freedom with a specific conception of human virtue,

291. JAMES, supra note 13 , at 175.

292. Id. at 51 .

293. Id. at 189 .

294. Id. at 201.

295. John Skorupski, Introduction: The Fortunes of Liberal Naturalism, in THE Cambridge Companion to Mill 1, 24 (John Skorupski ed., 1998). 
classical liberalism "assumes the objectivity" of its values. ${ }^{296}$ In the postbellum period, however, liberal values were increasingly difficult to reconcile with the realities of everyday life, and the assumption that those values provided an objective basis for legal and political judgments was correspondingly threatened. ${ }^{297}$ Sloper's liberalism requires respect for "freely-developed" individual diversity, ${ }^{298}$ but it cannot assimilate the diversity of values circulating outside his ideological purview yet, alarmingly, within his own house. The complex interactions of Sloper, Penniman, Catherine and Morris act out the collision of classical liberal, sentimental, Victorian, and laissez-faire values and expectations within American culture in the postbellum period, demonstrating, among other things, the inadequacy of classical liberalism generally, and legal science specifically, to effectively mediate that collision. Sloper's principled indifference to Catherine's actual experience mirrors the inereasingly incoherent effects of judicial decisions based in classical legal thought. ${ }^{299}$

Sloper's consistent response to the disconnect between his expectations and the realities around him is irony. By irony I mean "saying one thing when another is meant, not for the purpose of deceit and not wholly for the purpose of mockery (although this is usually implicit), but, rather, in order to establish a disconnection between the speaker and his interlocutor, or between the speaker and that which is being spoken about, or even between the speaker and himself." 300 The distancing effect of irony facilitates the "detachment"301 necessary to Sloper's categorical reasoning. But irony is also a tool in the establishment and maintenance of social hierarchies. ${ }^{302}$ And it is this kind of irony that Sloper has employed in relation to Catherine all her life, rather than

296. Id. at 24.

297. After all, classical legal thought's context was the first protracted period in America of the kind of economic and class conflict that had characterized the Western European countries during the period of rapid industrialization. The issues involved were the concentration of industry and finance combined with 'cut-throat' competition; the struggle between the farmers and the railroads; the struggle between unions and employers over working conditions and wages; the relation of state to federal governments in the regulatory process.

Kennedy, supra note 84, at 7; see also Forbath, supra note 24, at 767 (1985).

298. Skorupski, supra note 295, at 26.

299. See WIECEK, supra note 24, at 176-187 (describing early critiques of classical legal thought in action).

300. TrILliNG, supra note 204, at 120. Aristotle's "conception of irony" is "the man who deprecates himself" and the idea is that "[s]uch a inan makes himself invulncrable. . . The term irony, then, indicates a technique of appearing to he less tban one is, which in literature becomes most commonly a technique of saying as little and ineaning as much as possible." NORTHROP Frye, ANATOMY OF Criticism 40 (1957). See generally, Booth, supra note 43.

301. Trilling, supra note 204, at 121 .

302. Linda Hutcheon, Irony's Edge 17-18, 29, 40 (1994). 
directly "visit[ing] his disappointment upon the poor girl." 303 We are given glimpses of this irony early in the text: when she wears a dress he finds vulgar, he pays her the dubious compliment of looking "sumptuous, opulent, expensive ... as if you had [an income of] eighty thousand a year;", 304 when Morris makes his first social visit to her at Sloper's house in Washington Square (it is only Catherine and Morris's second meeting), the doctor asks, "[D]id he come here to propose to you?" 305 Rather than deigning to acknowledge Catherine's vulgar taste or unsophisticated credulity, Sloper uses irony to simultaneously assert his authority and dissociate himself from them.

Sloper is also consistently ironic in relation to Penniman, whom he finds ridiculous, and Morris, whom he finds "amazingly conceited." 306 Indeed, irony emerges as Sloper's primary tool for managing interactions with vocabularies (and corresponding expectations and values) discordant with his own. This use of irony makes perfect sense, but it carries a liability: in an ideologically and discursively heterogeneous setting, "where different positions or 'truths' theoretically coexist and are valued," irony is potentially unstable, increasingly susceptible to misreading. ${ }^{307}$ Both the deployment and reading of irony involve a "complex process of relating, differentiating, and combining said and unsaid meanings-and doing so with some evaluative edge." ${ }^{308}$ Irony deployed across diverse cultural vocabularies risks unanticipated misinterpretation because stable meanings depend upon shared expectations and assumptions within discursive communities. Ironies which arise in such settings also have the potential to reveal more about their subjects than their speakers may intend. And this is precisely what begins to happen in the collision of vocabularies in Washington Square.

When, upon his return from Europe, Penniman laments that Sloper has not "come home without that odious ironical tone," Sloper rejoins, "Don't undervalue irony; it is often of great use."309 But the use to which Sloper puts his talent for irony has evolved by this point in the novel. His experiment having turned out quite differently than he expected, irony becomes his defense against a situation over which he has lost control, a device to distance himself from the undesirable consequences of his own course of action. The first sign of this may be Sloper's ironic suggestion that Catherine's honesty and

303. JAMES, supra note 13, at 15. In Sloper's view "[t]here would have been a fitness in her being pretty and graceful, intelligent and distinguished-for her mother had bcen the most charming women of her little day-and as regards her father, of course he knew his value. He had moments of irritation at having produeed a commonplace child." Id. at 14.

304. Id. at 28 .

305. Id. at 37 .

306. Id. at 57 .

307. Hutcheon, supra note 302, at 16 (describing the increased possibilities for misunderstanding or failure of irony in "a more democratic situation").

308. HutcheON, supra note 302 , at 89.

309. JAMES, supra note 13 , at 164. 
obedience are in bad taste. During the scene with Catherine in the Alps, Sloper's assertion that "[ $\mathrm{t}]$ hough I am very smooth externally, at bottom I am very passionate" ${ }^{310}$ seems ironic-nothing we have seen or been told about the doctor, until this moment, suggests that he is in any way passionate. But there is reason to suspect that this irony actually reveals the tension between his social identity and his emotional life. Like Morris, he is not, perhaps, what he seems.

When Catherine makes it clear that she will not give Morris up, but is willing to wait for her father's approval, Sloper offers the ironic response, "Of course; you can wait till I die, if you like. . . . Your engagement will have one delightful effect upon you; it will make you extremely impatient for the event." Catherine, as always, misses the irony: Sloper's quip strikes her with "the force-or rather the vague impressiveness-of a logical axiom which it was not in her province to controvert." 311 Nevertheless, she attempts to reassure him with the response, "If I don't marry before your death, I will not after." 312 But here Sloper misses something too. He misinterprets her response to his irony as "an impertinence," 313 and from that moment the mistaken and paranoid suspicion that Catherine and Morris plan to marry after his death begins to grow in the rational doctor's mind. When, more than twenty years later, he hears that Morris is back in New York, he asks Catherine to promise not to marry Morris after his death. ${ }^{314}$ Catherine refuses because she feels that Sloper is "trying to treat her as he had treated her years before . . . and now, all her experience, all her acquired tranquility and rigidity protested." 315 Having shown no sense of paternal duty, Sloper does not, in Catherine's view, have the right to make such a request. But she is once again incapable of explaining herself to him. When he accuses her of being "obstinate," she answers "I don't think you understand" but "can't explain."316 Mistaking her dignity for confirmation of his suspicions, Sloper disinherits her anyway. ${ }^{317}$

This is an irony that Sloper does not intend. Indeed, there are many ironies of which Sloper is the author in Washington Square, but also a great many that James invites the reader to author. In its most straightforward manifestation, irony appears to require a speaker who intends the irony and a reader who decodes or reconstructs it. ${ }^{318}$ But as critics have widely recognized, this is not

310. Id. at 147 .

311. Id. at 113 .

312. Id. at 114 .

313. Id. at 114 .

314. Id. at 205.

315. Id.

316. Id.

317. In this way irony always potentially "masters the one who tries to master or take power with it." HuTCHEON, supra note 302, at 37 (quoting J.H. Miller).

318. Booth describes the proeess of reading - or in his phrase, "reconstructing"-irony as having four parts. First, something about the text itself requires the reader to reject its literal 
the only and may well be the least interesting way that irony arises. ${ }^{319}$ Washington Square abounds in what we understand to be unintended ironiesstatements we read as ironic whose speakers do not mean them to be-from the insensitive Morris's claim, "I am quick to feel," 320 to Penniman's suggestion that Catherine "never judged [Morris] rightly" 321 to Sloper's conviction that he "had never been wrong in his life, and he was not wrong now" 322 when Catherine cannot explain her refusal to promise not to marry Morris. Indeed, by the end of the novel the obstacles to mutual comprehension generated by the characters' disparate ways of talking about the world are most clear in the unintended ironies created by their interaction. As Catherine learns, nothing is "natural" in a heteroglossic world, and personal integrity, or sincerity, is only as stable as one's self-expression is correctly interpreted.

But more than that, in a world of inconsistent but overlapping vocabularies generated by a heterogeneous culture (in which difference increases exponentially along the axes of ideology, class, ethnicity, education, etc.) irony may not just be inevitable, it may become an important interpretive tool. Even where "an author presents no argument or position, claiming strict objectivity, indifference to the reader, or aesthetic impassivity, the reader will find himself choosing, perhaps unconsciously, to accept or reject the pose, or stand, or tone, or claim to poetic craft. But irony dramatizes this choice, forces us into hierarchical participation, and hence makes the results more actively our

meaning. "If hc is reading properly, he is unable to escape recognizing either some incongruity among the words or between the words and something else that he knows." BoOTH, supra note 43, at 10 . Second, "[a]lternative interpretations or explanations are tried out-or rather, in the usual case of quick recognition, come flooding in." Id. at 11. In order to choose between these alternatives, the reader must make a decision "about the author's knowledge or beliefs" about whether the author or speaker also rejects the meaning the reader has rejected, and whether the author "has reason to expect" the reader's concurrence. Finally, "having made a decision about the knowledge or beliefs of the speaker, we can finally choose a new meaning or cluster of mcanings with which we can rest secure." Id. at 12 .

It may well be that the steps are not sequential at all, and they might better be called something like elements, or even vectors. We often do take all of them 'in a flash,' and there may be in this some explanation of why irony is such a powerful weapon so much enjoyed by authors and readers alike. Perhaps no other form of human communication does so much with such speed and economy.

Id. at 13. As is clear from Booth's account, "ironic reconstructions depend on an appeal to assumptions, often unstated, that ironists and readers share." Id. at 33.

319. As Hutcheon explains,

[t]o call something ironic is to frame or contextualize it in such a way that, in fact, an intentionalist statement has already been made-either by the iromst or by the interpreter (or by both). In other words, intention/nonintention may be a false distinction: all irony happens intentionally, whether the attribution be made by the encoder or the decoder.

Hutcheon, supra note 302, at 118 (emphasis in original).

320. JAMES, supra note 13 , at 47.

321. Id. at 215 .

322. Id. at 206. 
own." 323 Ultimately, the disconnect between what is said and what is meant that we call irony "is neither the property of works nor the creation of an unfettered imagination, but a way of reading, an interpretive strategy that produces the object of its attention." 324

Irony as Sloper deploys it may be a liability under the modern conditions emerging in the 1870 s. But James clearly appreciates the value of irony in another sense-in its capacity to reveal the otherwise largely invisible heteroglossia, the multiple simultaneous vocabularies, of daily life. For James, irony is a tool for not just disclosing but also interrogating the unintended consequences and unexpected costs of contested values and expectations for individuals and society. ${ }^{325}$ The ironies that emerge in Washington Square reveal, among other things, the contemporaneous and inconsistent understandings of rights, duties, liberty, and value emerging not just from classical economics and legal orthodoxy but also from sentimentalism and Victorianism in the postbellum period. And recognizing the interaction of legal and non-legal understandings of these concepts bears particular relevance to Lochner era jurisprudence.

\section{IV}

\section{Competing Vocabularies in Postbellum Legal Discourse}

In 1883, William Graham Sumner, an early and important advocate of laissez-faire economic and social policy in America, observed that

there are yet mixed in our institutions mediæval theories of protection, regulation, and authority, and modern theories of independence and individual liberty and responsibility. The consequence of this mixed state of things is, that those who are clever enough to get into control use the paternal theory by which to measure their own rights - that is,

323. Booth, supra note 43 at 41 .

324. FISH, supra note 8, at 194. Fish acknowledges the apparent danger that "what is ironic will be for the reader to decide, for in the absence of independent criteria, he may see ironies or not as he pleases. This, however, is an empty fear" for the reason Fisb always identifies: "while there are no rules imposed by the work itself [ ], there are always rules, or rules of thumb, that are constitutive both of the possibilities and of the limits of what can be said and what can be demonstrated." Id. at 193-94.

That is to say, if irony is a way of reading, so is literalness; neither way is prior to the other, in the sense of being a mode of calculation rather than by interpretation; both are interpretive ways, which are set in motion by cues and considerations that are themselves in place as a consequence of an interpretive act.

Id. at 195 (emphasis in original).

325. Because it is "[a]n aggressively intellectual exercise that fuses fact and value, requiring us to construct alternative hierarchies and choose among them [ ] coupled with a kind of subtlety that cannot be deciphered or "proved' simply by looking closely at the words," irony is a particularly useful tool for locating discursive instability. "No wonder," Booth observes, "that 'failure to communicate' and resulting quarrels are often found where irony dwells." BоOTH, supra note 43 , at 44 . 
they assume privileges; and they use the theory of liberty to measure their own duties-that is, when it comes to duties, they want to be "let alone." 326

This curious combination of paternalist invocation of authority and formalist rejection of accountability provides an apt description of the results of Sloper's system in Washington Square. It also provides a fairly apt description of the progressive critique of the results of judicial rulings during the classical legal period. ${ }^{327}$ And, as in the Sloper household, legal orthodoxy's refusal to engage changing social conditions and the unintended outcomes of its rulings put the Court in increasingly ironic positions. ${ }^{328}$ Indeed, "nearly every historian who has written about the subject has felt obliged to produce some explanation, or model, for making sense out of what looks very much like Justices simply writing down their political views and calling it constitutional adjudication." 329

For much of the twentieth century, the progressive charge that legal orthodoxy had fashioned "elaborate and unprincipled doctrines ... out of whole cloth in order to declare unconstitutional federal and state legislation that threatened the well-being of corporations and wealthy Americans" dominated American legal-historical memory. ${ }^{330}$ But in recent decades, the jurisprudence of what has come to be known as the Lochner era has been reinterpreted. Lochner era revisionists have argued that legal orthodoxy was not only coherent and principled, but largely consistent with antebellum legal principles. ${ }^{331}$ They have also argued that the apparent incoherence of the legal outcomes of the period resulted from unprecedented social and economic

326. William Graham Sumner, What the Social Classes Owe to Each Other 15051 (1883).

327. In Herbert Hovencamp's account,

The central problem of the Fuller Court was that it united its prejudices with an expansive and ill-considered conception of judicial power that enabled the Justices to strike down all manner of legislation by employing highly creative interpretations of the Constitution. Then it used that power selectively. For example, 'due proeess' was given a broad and unprecedented meaning in Lochner, but 'equal protection' was constrained to its narrowest possible meaning in Plessy.

Herbert Hovencamp, The Culture Crises of the Fuller Court, 104 YALE L. J. 2309, 2310 (1995); see also WIECEK, supra note 24, at 175-207 (describing the progressive and legal realist critiques of legal science); Howard Gillman, The Constitution Besieged: The Rise and Demise of Lochner Era Police Powers Jurisprudence 208-208 (1993) (describing the progressive charge that legal scienee served class interests).

328. Wiecek offers a comprehensive summary of these ironies in terms of the disconnect between the Court's rulings and postbellum economic, technological, and social change. WIECEK, supra note 24, at 248-252; see also id. at 126-133 (describing the problematic results of legal classicism in state court rulings).

329. Hovencamp, supra note 327, at 2312.

330. Gary D. Rowe, Lochner Revisionism Revisited, 24 Law \& Soc. Inquiry 221, 222 (1999).

331. Id. at 224-231, 235. See also Wiecek, supra note 24, at 19-54 
upheaval, rather than ideologically activist judges. ${ }^{332}$

Lochner era revisionism has, as Gary Rowe argues, usefully insisted on the relevance of historical context and particularly "socially constructed forms of thought" for constitutional scholarship. ${ }^{333}$ But the revisionists' narrow focus on legal orthodoxy's reasoning obscures the legal outcomes that prompted the progressive critique they reject. ${ }^{334}$ Indeed, Rowe asserts that the narrowness of the revisionist project indicates the necessity of broader legal-historical work on the period, "laying the groundwork for a new set of approaches to problems of American constitutionalism." 335 I propose that reading for the discursive instabilities that emerge from the competing cultural vocabularies judges employ contributes to our understanding of the jurisprudence of the period, and that fiction often helps locate those discursive instabilities. The dizzying array of unprecedented legal questions legal orthodoxy faced put its methods and assumptions to the test. Most of these questions implicated the legal conceptions of rights, duties, liberty and value. ${ }^{336}$ And the answers that courts gave often reflected the heteroglossia of the period.

Postbellum legal opinions are peppered with collisions between the competing cultural vocabularies James captures in Washington Square. Take, for example, the odd combination of Victorian rhetoric and legal formalist reasoning in Bradwell v. State. In 1869, Myra Bradwell, a thirty-eight-year-old mother of two who had apprenticed with her Iawyer husband, passed the Illinois bar exam with high honors but was denied admission to the bar by the

332. See, e.g., Horwitz, supra note 27 , at 30 (asserting that the realities of a developing industrial society disclosed the limitations of traditional constitutional doctrines). William Forbath observes that while the "standard story among historians and economists of virtually all ideological hues has long bcen that economic and technological imperatives dictated the outcome of the Gilded Age's industrial conflicts and the triumph, by the 1920s, of mass production under the aegis of private corporate capital," "far more was up for grabs, and far less determined by some essential logic of economics or technological development, than the standard story admits." Forbath, supra note 24, at 771; see also Rowe, supra note 330, at 232-233 (describing revisionist arguments).

333. Rowe, supra note 330 , at 240 (quoting Gillman, supra note 323 , at 199).

334. Id. at 240 .

335. Id. at 250; see also id. at 245-247.

336. Horwitz details the expansion of property rights and the difficulty of determining value in the late nineteenth century. HoRwITZ, supra note 27, at 145-169; see also FRIED, supra note 36, at 71-107 (discussing the "empty idea of property rights" in the classical period). Fried offers an analysis of the challenges to classical notions of liberty. Id. at 29-70. On the effects of classical freedom of contract under new market conditions, see HoRwITZ, supra note 27, at 33-64; WIECEK, supra note 24, at 126-133. On the relationship hetween rights and duties in the law of torts in the period see John C.P. Goldberg, The Constitutional Status of Tort Law: Doe Process and the Right to a Law for the Redress of Wrongs, 115 YALE L.J. 524, 564-575 (2005); John C.P. Goldberg \& Benjamin C. Zipursky, The Moral of Macpherson, 146 U. PA. L. REv. 1733, $1746-$ 1756 (1998). Revisionists tend to describe Lochner era jurisprudence in terms of a specific conception of liberty that restricted government power to very specific spheres of activity. Rowe, supra note 330 , at $226-230$. 
Illinois Supreme Court. ${ }^{337}$ Her appeal reached the Supreme Court. Writing for the majority, Justice Miller is categorical: “. . . [T] here are privileges and immunities belonging to citizens of the United States . . . . But the right to admission to practice in the courts of a state is not one of them." 338 In contrast with this apparently gender neutral holding, Justice Bradley's concurrence articulates the Victorian ideal of separate domestic and public spheres. ${ }^{339}$ "The harmony," he writes, "not to say identity of interests and views which belong or should belong to the family institution, is repugnant to the idea of a woman adopting a distinct and independent career from that of her husband . . . The paramount destiny and mission of women are to fulfill the noble and benign offices of wife and mother." ${ }^{340}$ Both the detachment of Miller's reasoning and the effusiveness of Bradley's rhetoric elide the social realities Myra Bradwell's application for admission to the bar embodied. Their combination in Bradwell registers the extent to which extralegal cultural vocabularies informed legal discourse.

Miller's short Bradwell opinion relies on the recently decided Slaughterhouse Cases. In Slaughterhouse the Supreme Court held that two hundred butchers excluded from a state-created monopoly in and around New Orleans had not been deprived of their Fourteenth Amendment rights because the Thirteenth and Fourteenth Amendments only applied to former slaves. ${ }^{341}$ William Forbath has carefully examined the inconsistent ideological positions contained in Slaughterhouse and argues that while Justice Field asserted in his dissent that the monopoly violated the right to freely sell one's labor, ${ }^{342}$ Field conceived that right in terms of traditional republican values, in which "[f]reedom meant economic independence, [and] ownership of productive property - not as an end in itself primarily but because such independence was essential to participating freely in the public realm." ${ }^{343}$ Nevertheless, Field's

337. Jane M. Friedman, Myra Bradwell: On Defying the Creator and Becoming a Lawyer, 28 VAL. U. L. REV. 1287, 1288-1289 (1993).

338. Bradwell v. The State, 83 U.S. 130, 139 (1873).

339. Jane Friedman argues that Justice Bradley felt the necessity of offering an alternate account because he had written, in a lower court opinion in Slaughterhouse (also 1873) that "there is no more sacred right of citizenship than the right to purse unmolested a lawful employment in a lawful manner." Friedman, supra note 337, at 1298. Friedman suggests that Bradley believed that the distinction between male and female roles "was ordained by God" but the language he uses is distinctly Victorian. $I d$. at 1299.

340. 83 U.S. 130 at 141.

341. Forbath, supra note 24 , at $772-773$.

342. 83 U.S. 130 at 110.

343. Forbath, supra note 24 , at 775 . On this account, the "propertyless 'servant' or 'hireling' was an untrustworthy citizen." $I d$. at 775.

But Slaughterhouse remained virtually the only case in which the right to pursue one's calling was invoked on behalf of working men or women who also owned productive property. The scores of subsequent decisions in which Field's opinion figured as a leading precedent do not breathe a word about the free laborer's right to the 'fruits of his labor.' The working men 
dissent, which would become federal constitutional law with Lochner, borrowed extensively from the brief submitted by the butchers' attorney, exJustice Campbell. And Campbell's argument hinged on the laissez-faire proposition that "the Reconstruction amendments rendered the Constitution a charter for a free marketplace." 344 The difference between the republican ideal of the right to acquire property through "artisanal and petty entrepreneurial production" and the right to sell one's labor in a labor market was obscured, for Field and others, by Abolitionist "free labor" rhetoric, which conceived of Northern wage labor in terms of the freedom of self-ownership, in contrast with slavery. ${ }^{345}$ In other words, Forbath shows that the heterogeneous ideologies of the period combined to create unintended or unstable meanings in the opinion. $^{346}$

The rhetoric of what Forbath describes as anticapitalist republicanism is heavily inflected with Victorian values and assumptions. In Victorian culture, work "forged bonds of obligation guaranteed by personal honor, public usefulness validated private effort, and steady application assured social order. Overall, they thought community standards should mediate individual efforts . . . because they saw the products of their labor as personal contributions to communities." ${ }^{, 347}$ Justice Miller's indifference, writing for the majority, to the fact that the new slaughterhouse corporation's "privileges are at the expense of the community" is fundamentally at odds with the Victorian conception of a "sphere of equality" embracing community and work relations"348 which informs the language and logic of both the Field and Bradley dissents. ${ }^{349}$ The "liberty" to choose the manner of one's contribution to the community-which, for Victorians, was synonymous with the "pursuit of happiness"-is qualitatively different than the "liberty" to sell one's labor in an unrestricted market. ${ }^{350}$ As Forbath notes, the meaning of the right to sell one's labor and Id. at 781-782.

and women in this prodigious line of cases were . . . all wage-earners.

344. Id. at 780; see also WIECEK, supra note 24 , at 125.

345. Forbath, supra note 24 , at 783.

346. "Irony" arises in Slaughterhouse, Forbath observes, from the "fact that both outlooks, the courts' liberal orthodoxy and the labor movement's anticapitalist republicanism, had a common origin" in classical liberalism. The "judges who struck down the labor laws and the labor reformers who promoted them claimed to act on behalf of many of the same ideals: the workingman's 'independence,' the dignity of 'free labor,' its deliverance from 'coercion' and 'paternalism."' Id. at 769.

347. Rose, supra note 268 , at 71 .

348. Forbath, supra note 24 , at 799.

349. For example, the attention to "the mutual good of all" in Bradley's description of the "the fundamental rights" of life, liberty and property and his assertion that the Fourteenth amendment "was an attempt to give voice to the strong National yearning" for the social stability and security of the pre-Civil War era. 83 U.S. 36,123 (1873).

350. If the right to sell one's labor is linked to the community in which it is sold, that right is impaired by state aetion affeetimg it. See, e.g., Fried's discussion of a contemporary competmg " "positive' notion of liberty that measured the individual's power to affect his of her desires" 
liberty of contract that evolved from Field's dissent in opinions like Allgeyer $v$. State of Louisiana, Lochner v. New York, and Adair v. US was very different from the meaning Field intended. ${ }^{351}$

Much of the discursive instability in Lochner era opinions can be read in terms of incompatible understandings of rights, duties, and liberties arising from Victorian, classical liberal, and legal formalist vocabularies. ${ }^{352}$ But laissez-faire and sentimental language also occasionally penetrated legal discourse. In In re Debs, ${ }^{353}$ for example, the Court turns a deaf ear to the "most earnest and eloquent appeal" made in "eulogy of the heroic spirit" of those who "gave up their means of earning a livelihood . . . in sympathy for and to assist others whom they believed to be wrong." 354 The ruling is surely a conservative rejection of what is described as the "mob violence" of the strikers. ${ }^{355}$ But it also registers a failure on the part of the strikers' attorneys to correctly gauge the appropriate vocabulary through which to defend their clients. The sentimental rhetoric employed by the labor movement's lawyers had abundant cultural resonance in 1895 , but no legal authority. The Court's response was to teach the culture of sentiment "a lesson" in the correct language for redressing a wrong. ${ }^{356}$ But the fact that the Court found it necessary to do so suggests the extent to which it perceived sentimentalism as a viable threat to social and legal order. Coppage v. Kansas presented the Court with another dispute between labor and railroads, this time to do with a railroad's right to prevent employees

following the English Victorian political philosopher T. H. Green. FrIED, supra note 36, at 37. See also Justice Field's dissent in Munn v. Illinois, 94 U.S. 113, 142 (1876) ("By the term 'liberty' ... something more is meant than mere freedom from physical restraint. . . 1t means freedom to go where one may choose, and to act in such a manner, not ineonsistent with the equal rights of others, as his judgment may dictate for the promotion of his happiness."). Here Field is advocating for the kind of freedom Catherine expects, not the kind Morris exploits.

351. Forbath, supra note 24, at 781-782. ("Slaughterhouse remained virtually the only case in which the right to pursue one's calling was invoked on behalf of working men or women who also owned productivc property. The scores of subsequent decisions in which Field's opinion figured as a leading precedent do not breathe a word about the free laborer's right to the 'fruits of his labor,' The working men and women in this prodigious line of eases were . . . all wageearners.").

352. For example, Justice Harlan's dissent in the Civil Rights Cases (1883) indicts the majority for hypocrisy in its "too narrow and artificial" construction of the Thirteenth and Fourteenth amendments. 109 U.S. 3, 26. Harlan details the ways the majority has "departed from the familiar" mode of constitutional interpretation in its categorical and ahistorical abstractions. Id. at 42. And Harlan's charge that "the substance and spirit" of the amendments "have been sacrificed by a subtle and ingenious verbal criticism" suggests Harlan's sense of the irony inherent in subjecting the Civil Rights Acts to the formalist logic of legal orthodoxy. Id. at 26. In Harlan's reading, the majority simply can't plausibly mean what it says. In this way, he offers a critique of the discursive praetiees of legal orthodoxy as discursive practices.

353. At stake was the right of the federal government to intervene in a local railroad strike.

354. In re Debs, 158 U.S. 564, 598 (1895).

355. Id. at 598 .

356. Id. at 599 . 
from joining unions. ${ }^{357}$ Finding for the railroad, Justice Pitney reasons from what was by then the well-established "right of a person to sell his labor" free from state intervention to a corollary "right of the purchaser of labor to prescribe the conditions upon which he will accept such labor." 358 In the process, he employs the distinctly laissez-faire description of sellers and buyers of labor as equally "free agents" in a properly unregulated market. ${ }^{359}$ it is easy to see how progressive and legal realist critics read decisions like Coppage as nakedly ideological. Still, the clashing perspectives and practices of the period left open the question of whether the logic of laissez-faire might be preferable to the alternatives - a question James raises without an easy answer in Washington Square.

In the classical legal period, William Wiecek argues, "language, especially of text and precedent, took on a life of its own . . . . In a method heavily dependent on logic and as indifferent to social reality as classicism, words held sway, providing verbal formulas that were cndlessly manipulable by judges." 360 Judges may well have been manipulating language, but the instability of the language available to judges - caused by competing cultural conceptions loading specific words with multiple incompatible meanings-may also have compromised their verbal formulas. As Wai Chee Dimock has observed, law "is a linguistic artifact, dependent on words and haunted by that dependency." 361 My reading of Washington Square suggests that works of fiction can usefully reveal not merely the cultural assumptions and expectations but also the various linguistic meanings that inform legal texts. Indeed, attending to literary representations of law may be particularly constructive for periods of significant cultural change, during which articulations of values and the selves we create through those articulations invariably become diffuse and unstable.

357. 236 U.S. 1 (1915).

358. Id. at 10 .

359. Id. at 9. Duncan Kennedy refers to this as the "classic illustration" of "individualist political, moral and economic theory." Kennedy, supra note 44, at 1731.

360. WIECEK, supra note 24, at 81.

361. Moreover, "as words change their meaning, so to do laws whose wording might remain superficially the same. To enforce the letter of the law is paradoxically to depart from its original meaming, changing its scope and its mode of operation, getting it tangled up in complications entirely unforeseen." Dimock, supra note 28 , at 238 . 